\title{
Abstention, Separation of Powers, and the Limits of the Judicial Function
}

\author{
Martin H. Redish $\uparrow$
}

The federal courts have long assumed the authority to decline to exercise jurisdiction explicitly vested in them by Congress. The courts have also assumed that they may decline to enforce certain substantive federal rights, usually those protecting individual civil liberties against state invasion. These presumptions of authority are manifested in the various "abstention" doctrines, developed by the federal courts largely within the last fifty years. ${ }^{1}$ While the abstention doctrines have most often been applied in cases invoking only the federal courts' civil rights jurisdiction, in certain instances they sweep both civil rights and other forms of jurisdiction within their reach. ${ }^{2}$ In still other cases, they have been applied to exercises of federal jurisdiction wholly devoid of civil rights concerns, such as diversity. ${ }^{\mathbf{3}}$

The federal courts have assumed this authority, even in the absence of legislative history or statutory language authorizing such a refusal to act. Surprisingly, few have questioned whether the federal judiciary's authority to take such action violates the separation of governmental powers. To be sure, both scholars and jurists have criticized the efficacy and wisdom of the various abstention doctrines. ${ }^{4}$ But they have left largely untouched

$\dagger$ Professor of Law, Northwestern University School of Law. A.B. University of Pennsylvania, 1967; J.D. Harvard Law School, 1970. I would like to express my appreciation to Professors John E' zon, William Marshall, Richard Matasar, Thomas Merrill, and Cass Sunstein, and to Judges Marvin Aspen and Richard Posner, all of whom made helpful comments and suggestions. Of course, the views expressed are solely my own. I would also like to thank Andrea Sussman of the class of 1985 and Brian Caminer of the class of 1986 at Northwestern University School of Law for their invaluable research assistance.

1. See M. Redish, Federal Jurisdiction: Tensions in the allocation of Judicial Power 233-58, 291-321 (1980); C. WRIGHT, LAW of Federal Courts 302-30 (4th ed. 1983); Field, Abstention in Constitutional Cases: The Scope of the Pullman Abstention Doctrine, 122 U. PA. L. Rev. 1071 (1974).

2. An example is the so-called Colorado River abstention in the face of parallel state proceedings. See discussion infra pp. 96-98.

3. The exceptions to diversity jurisdiction for probate and domestic relations matters are examples. See discussion infra pp. 102-05.

4. See, e.g., Field, supra note 1; Fiss, Dombrowski, 86 Yale L.J. 1103 (1977); Laycock, Federal Interference with State Prosecutions: The Need for Prospective Relief, 1977 SuP. CT. REv. 193; Wechsler, Federal Courts, State Criminal Law and the First Amendment, 49 N.Y.U. L. REv. 740 (1974). 
the important question of the federal judiciary's authority to ignore the dictates of valid jurisdictional and civil rights statutes. ${ }^{5}$

Presumably no one would deny that a federal court cannot legitimately invalidate a federal statute solely because of its unwise policies, or because it would make judges work harder than they believe they should, or because the judges themselves would not have enacted such legislation. Such behavior by the judiciary would amount to a blatant-and indefensible-usurpation of legislative authority. At most, the judiciary possesses authority to overturn federal legislation because it is unconstitutional, ${ }^{6}$ not because the judiciary considers it unwise. Yet, in a sense, the abstention doctrines amount to such usurpation.

The questionable logic underlying traditional abstention has been taken to an extreme in recent years by members of the judiciary who argue that state court adjudication of federal rights against the states is generally to be preferred to federal court adjudication. " These "total abstention" theories would effectively prohibit the federal courts from enforcing federal civil rights laws, in particular section $1983,{ }^{8}$ and from exercising their congressionally-vested jurisdiction to enforce those laws. ${ }^{\circ}$ The term "total abstention" may be technically inaccurate, for these theories usually purport to preserve some jurisdiction for the federal courts to exercise. ${ }^{10}$ But as a practical matter, the abstention is total, and this seems to be the goal of the theories' supporters.

5. This is true of all of my previous writing, which has questioned various judge-made abstention doctrines solely on the basis of policy considerations. E.g., Redish, The Doctrine of Younger v. Harris: Deference in Search of a Rationale, 63 CORNELI. L. REv. 463 (1978). At least one commentator has persuasively questioned the viability of the judge-made equitable abstention doctrine of Younger $v$. Harris, 401 U.S. 37 (1971), by examining the legislative history of the Civil Rights Act of 1871, ch. 22, 17 Stat. 13 (codified as amended at 42 U.S.C. $\$ 1983$ (1982)). See Zeigler, A Reassessment of the Younger Doctrine in Light of the Legislative History of Reconstruction, 1983 DUKE L.J. 987. However, to date no commentator has undertaken a structural separation-of-powers analysis of the entire range of judge-made abstention.

6. Indeed, the extent to which the courts can do even this has been the subject of recent vigorous debate. Compare M. Perry, The Constrtution, the Courts, and Human Rights (1982) with J. Ely, Democracy and Distrust (1980).

7. Justice Rehnquist is the foremost advocate of this view, although Chief Justice Burger is of the same school. See discussion infra pp. 105-10.

8. 42 U.S.C. $§ 1983$ (1982) provides:

Every person who, under color of any statute, ordinance, regulation, custom, or usage, of any

State or Territory or the District of Columbia, subjects, or causes to be subjected, any citizen of the United States or other person within the jurisdiction thereof to the deprivation of any rights, privileges, or immunities secured by the Constitution and laws, shall be liable to the party injured in an action at law, suit in equity, or other proper proceeding for redress . . . . 9. 28 U.S.C. $\S 1343$ (a) (1982), provides:

The district courts shall have original jurisdiction of any civil action authorized by law to be commenced by any person: . . . (3) To redress the deprivation, under color of any State law, statute, ordinance, regulation, custom or usage, of any right, privilege or immunity secured by the Constitution of the United States or by any Act of Congress providing for equal rights of citizens or of all persons within the jurisdiction of the United States . . . .

10. See discussion infra pp. 105-10. 
The burden of production in the abstention debate has been improperly reversed. The primary battleground has generally concerned the debate over whether state courts could protect federal rights as effectively as federal courts. Those who argue for either the adoption of "total abstention" or for the continuation or expansion of existing "partial abstention" raise various arguments founded in either social policy, ${ }^{11}$ federalism, ${ }^{12}$ or judicial efficiency. ${ }^{13}$ They usually develop their arguments as if we were attempting to establish, on a totally clean slate, the wisest system of judicial federalism, in total disregard of the detailed and carefully balanced existing statutory network. Even more surprising, perhaps, is that many who oppose this argument have been willing to approach the problem on these terms, constantly seeking to demonstrate that federal courts are in fact superior to state courts as enforcers of federal rights. ${ }^{14}$ In my opinion, the arguments that federal courts are superior are overwhelming. ${ }^{15}$ But that should not be the point of contention, nor is it the point of this Article.

The central difficulty with the argument for abstention is the forum to which it has been directed. Nothing, of course, prevents those who believe in the fungibility of state and federal courts as protectors of federal rights

\footnotetext{
11. See discussion infra pp. 111-12.

12. See discussion infra pp. 88-95.

13. See discussion infra pp. 96-97.

14. See, e.g., Laycock, supra note 4; Neuborne, The Myth of Parity, 90 HaRv. L. REv. 1105

(1977); Redish, supra note 5.

15. These arguments are the following:

[T] he dramatic changes in the philosophy of federalism, culminating in the Civil War and enactment of the post-Civil War constitutional amendments and statutes limiting state power to interfere with federal rights, dictated a corresponding shift in the balance of judicial power between state and federal courts. Post-Civil War Congresses expressed grave mistrust of state court willingness to protect federal rights and to further federal interests. While of course state court ability or willingness to protect federal rights cannot be absolutely measured by the realities present over a hundred years ago, the changes in federal jurisdiction introduced at that time have had a far-reaching effect, both practically and philosophically, on the relative capabilities of state and federal courts in the modern federal system. Since that time federal courts have developed a vast expertise in dealing with the intricacies of federal law, while the state judiciary has, quite naturally, devoted the bulk of its efforts to the evolution and refinement of state law and policy. It would be unreasonable to expect state judiciaries to possess a facility equal to that of the federal courts in adjudicating federal law. Moreover, because federal judges are guaranteed the independence protections of Article III, while many state judges are forced to stand for election, we can generally be assured of a greater degree of independence of the federal judiciary from external political forces. When the issue is which court system is better able to protect minority rights from majoritarian infringement, this is not an insignificant factor. Finally, because of the process of presidential selection and Senate confirmation, we can usually be assured of a floor of competence on the federal judiciary.
}

M. REDISH, supra note 1, at 2-3 (footnotes omitted). See also Redish, supra note 5 (suggesting superiority of federal courts as protectors of federal rights). In one earlier piece, I argued that because state courts lack the independence protections of Article III, they do not meet the requirements of the due process clause in cases challenging the constitutionality of state action. Redish, Constitutional Limitations on Congressional Power to Control Federal Jurisdiction: A Reaction to Professor Sager, 77 Nw. U.L. REv. 143, 161-66 (1982). 
from attempting to convince Congress to repeal or substantially modify the broad jurisdiction it has vested in the federal courts. Generally, however, the arguments have not been directed to the legislative arena, but instead to the judicial forum, which is somehow believed to possess authority to alter or overrule the legislative directives.

Democratic principles clearly prohibit the judiciary from effectively repealing the statutory structure through "total abstention." It is doubtful that the "partial abstention" model is substantially more consistent with American political theory. One could persuasively argue that whatever social harms may flow from federal judicial enforcement of federal rights against state entities cannot-short of a finding of unconstitutionality-justify judicial abandonment of federal legislation. Even if we were to accept that, in extreme cases, the judiciary may create "safety valve" exceptions to otherwise unlimited legislation, the focus of the policy argument does not become whether state courts could do as good a job as federal courts; Congress has left the resolution of this issue to the plaintiff's choice of forum..$^{16}$ If it is to be employed at all, a safety valve should be recognized only in narrowly defined circumstances where state interests are so overwhelmingly undermined by federal, rather than state, adjudication that Congress could not possibly have contemplated or desired such a result. Thus refocused, the policy debate-to the extent that the separation-of-powers principle is construed to allow the courts to engage in such a debate-becomes whether federal adjudication would have a truly catastrophic effect on state interests. The only way that question can be answered is by examining how the world of judicial federalism would function if all forms of judge-made abstention were simultaneously to disappear.

This Article argues that neither total nor partial judge-made abstention is acceptable as a matter of legal process and separation of powers, wholly apart from the practical advisability of either form of the doctrine. Moreover, it suggests that the high transaction costs imposed by most forms of these abstention doctrines are not justified by their supposed benefits, ${ }^{17}$ and that their total abolition would not seriously undermine the efficient workings of judicial federalism. It concludes that the interests of federalism would be sufficiently protected by existing statutorily-dictated abstention, ${ }^{18}$ by long established equitable

16. See Zwickler v. Koota, 389 U.S. 241, 248 (1967): "In thus expanding federal judicial power, Congress imposed the duty upon all levels of the federal judiciary to give due respect to a suitor's choice of a federal forum for the hearing and decision of his federal constitutional claims."

17. See discussion infra pp. 91-98.

18. Such statutorily-dictated abstention is found in the Anti-Injunction Act, 28 U.S.C. $\$ 2283$ (1982); the Tax Injunction Act of 1937, 28 U.S.C. \& 1341 (1982); the Johnson Act of 1934, 28 U.S.C. $§ 1342$ (1982); the since-modified Three-Judge Court Act, 28 U.S.C. $\S 2284$ (1982); and the 


\section{Abstention}

limitations, ${ }^{10}$ and by the contours and limits of the substantive federal rights being enforced. ${ }^{20}$ Thus, little would be lost and much gained by simple judicial adherence to the valid legislative commands of existing federal substantive and jurisdictional enactments. Even if we were to conclude that unwavering judicial enforcement of this legislation actually would cause serious social harm, the recourse certainly should not be to the equivalent of judicial civil disobedience, but rather to the democratically ordained legislative process.

\section{The Partial Abstention Model as a Judicial Usurpation of Legislative Authority}

The various forms of partial abstention ${ }^{21}$ arise regularly in federal litigation, primarily (although not exclusively) in cases under the federal civil rights jurisdiction. Perhaps the best known type is so-called Pullman abstention, developed in Railroad Commission of Texas v. Pullman, ${ }^{22}$ under which a federal court will delay the exercise of its jurisdiction to allow a state court to interpret an ambiguous state statute subjected to a constitutional challenge. The doctrine is invoked only when the challenged statute is capable of at least two constructions, one which would render the law unconstitutional and one which would not. The case may ultimately return to the federal court for adjudication of the constitutional claim, ${ }^{23}$ but only after the state courts have definitively interpreted the statute. ${ }^{24}$

The Younger v. Harris ${ }^{25}$ abstention doctrine provides that a federal court may not enjoin an ongoing state criminal proceeding, even to protect federal constitutional rights. The Supreme Court has also applied the doctrine to the issuance of declaratory relief ${ }^{2 B}$ and to certain state civil proceedings that implicate important state concerns. ${ }^{27}$

In Burford v. Sun Oil Co. ${ }^{28}$ the Supreme Court ordered abstention in

exhaustion requirement in habeas corpus, 28 U.S.C. $\S 2254(b)$ (1982). See discussion infra pp. 81-82.

19. By this I refer to non-federalism based limitations on the grant of equitable relief. See discussion infra pp. 85-86.

20. See discussion infra p. 93.

21. Because the various forms of abstention have been described in detail elsewhere, this section will provide only their essential elements. For more detailed analysis, see the sources cited supra note 1.

22. 312 U.S. 496 (1941).

23. See England v. Louisiana State Bd. of Medical Examiners, 375 U.S. 411, 415-17 (1964).

24. See M. ReDish, supra note 1 , at 255-58.

25. 401 U.S. 37 (1971).

26. See Samuels v. Mackell, 401 U.S. 66, 73 (1971).

27. See, e.g., Trainor v. Hernandez, 431 U.S. 434, 444 (1977) (state interest in preventing welfare fraud); Juidice v. Vail, 430 U.S. 327, 335 (1977) (state contempt power).

28. 319 U.S. 315, 332 (1943). See also Alabama Pub. Serv. Comm'n v. Southern Ry., 341 U.S. 341, 349-50 (1951) (federal court will abstain in suit challenging constitutionality of commission order requiring railroad to continue in operation). 
order to prevent federal judicial interference in complex state administrative schemes. The Court also found abstention appropriate in Louisiana Power $\mathcal{O}^{2}$ Light Co. v. City of Thibodaux, ${ }^{29}$ a case concerning the validity of state expropriation of property. Although the presence of a parallel proceeding in a state court generally does not justify the dismissal of a federal suit, in Colorado River Water Conservation District v. United States ${ }^{30}$ the Court held that "exceptional" circumstances may justify a stay. Finally, in Parratt $v$. Taylor, ${ }^{31}$ the Court interpreted the due process clause to be satisfied by the provision of a state tort remedy for certain constitutional violations by state officers. While this decision purports to represent constitutional interpretation, in fact it amounts to a form of jurisdictional abstention. ${ }^{32}$

Each of these variants of the partial abstention model could be characterized as a judicial usurpation of legislative authority, in violation of the principle of separation of powers. The principle of separation of powers between the judicial and legislative branches derives from the fundamental democratic principle of electoral accountability. ${ }^{33}$ The separation-ofpowers critique of the partial abstention model begins with an analysis of the judiciary's proper role in a democratic society. The essential element of any democratic society is at least some level of majoritarian selfdetermination. ${ }^{34}$ In our form of constitutional democracy, we have chosen to vest in a largely unrepresentative judiciary the power to invalidate laws adopted by a majoritarian legislature when those laws are deemed to violate constitutional protections. ${ }^{35}$ It has never been suggested, however, that the judiciary may openly ignore a legislative judgment on any grounds other than unconstitutionality. Though the Supreme Court has reiterated this reasoning on a number of occasions, ${ }^{36}$ its statement in TVA v. Hill ${ }^{37}$ describes the principle as well as any:

Our system of government is, after all, a tripartite one, with each branch having certain defined functions delegated to it by the Consti-

\footnotetext{
29. 360 U.S. 25,30 (1959).

30. 424 U.S. $800,818-20$ (1976).

31. 451 U.S. 527, 543-44 (1981).

32. See discussion infra pp. 98-101.

33. See Merrill, The Common Law Powers of Federal Courts, 52 U. CHI. L. Rev. (1985) (forthcoming).

34. As Professor Peter Bachrach has stated, "[d]emocratic participation . . . is a process in which persons formulate, discuss, and decide public issues that are important to them and directly affect their lives." Bachrach, Interest, Participation, and Democratic Theory, in PARTICIPATION IN PoLITICS: Nomos XVI 39, 41 (J. Pennock \& J. Chapman eds. 1975).

35. This has been accepted at least since the decision in Marbury v. Madison, 5 U.S. (1 Cranch) 137 (1803).

36. See, e.g., California v. Sierra Club, 451 U.S. 287, 298 (1981); Touche Ross \& Co. v. Redington, 442 U.S. 560,576 (1979).

37. 437 U.S. 153 (1978).
} 


\section{Abstention}

tution. While "[i]t is emphatically the province and duty of the judicial department to say what the law is," . . . it is equally-and emphatically-the exclusive province of the Congress not only to formulate legislative policies and mandate programs and projects, but also to establish their relative priority for the Nation. Once Congress, exercising its delegated powers, has decided the order of priorities in a given area, it is for the Executive to administer the laws and for the courts to enforce them when enforcement is sought. ${ }^{38}$

Thus, Congress, exercising its power under section 5 of the Fourteenth Amendment, ${ }^{39}$ has established a network of federally protected substantive rights and simultaneously vested the federal courts with jurisdiction to enforce those laws, and the Supreme Court lacks the authority to ignore or invalidate those statutes merely because of disagreement with their substance. Viewed in the light of the separation-of-powers principle, then, virtually all the debate over the relative competence of federal and state courts as enforcers of federal rights becomes logically irrelevant, except to the extent it is directed exclusively to a call for legislative revision.

Conceptually, at least as a prima facie matter, there is little difference in this context between total and partial abstention. If Congress intended that the federal courts exercise a particular jurisdiction, either to achieve substantive legislative ends or to provide a constitutionally-contemplated jurisdictional advantage, a court may not, absent constitutional objections, repeal those jurisdictional grants. But one may question why, if the courts do not possess the institutional authority to repeal the legislature's jurisdictional scheme, they possess any greater authority to modify the scheme in a manner not contemplated by the legislative body. In either repealing or modifying the legislation, the court would be altering a legislative scheme because of disagreement with the social policy choices that the scheme manifests. Thus, if a judge-made form of partial abstention is inconsistent with congressional intent to leave federal court jurisdiction unlimited, the fact that the abstention leaves intact a portion of the jurisdictional grant will not insulate it from a separation-of-powers attack. ${ }^{40}$

The foundation of the separation-of-powers critique is the assumption that judge-made partial abstention conflicts with congressional goals em-

38. Id. at 194, quoting Marbury v. Madison, 5 U.S. (1 Cranch) 137, 177 (1803).

39. U.S. CoNST. amend. XIV, $\S 5$ provides: "The Congress shall have power to enforce, by appropriate legislation, the provisions of this article."

40. By way of analogy, if Congress enacted a substantive federal right of libel and slander in interstate commerce, a federal court would violate separation of powers if it ignored the legislatively dictated jurisdiction to enforce the statute simply because the court disagreed with its merits. The court would depart no less from accepted institutional norms if it were instead to "modify" the statute by ignoring the cause of action for slander and enforcing only the cause of action for libel. While such judicial action leaves intact a portion of the congressional scheme, the decision to ignore another portion of that scheme clearly usurps legislative authority. 
bodied in the seemingly unlimited grants of jurisdiction. It is the validity of this assumption that arguably separates the total and partial abstention models as departures from separation-of-powers principles. Various models of implied congressional authorization may be employed to justify partial abstention, but they are incapable of supporting total abstention. While it is at least conceivable that Congress would implicitly delegate to the judiciary the authority to modify or limit a substantive statutory right or a jurisdictional grant, ${ }^{41}$ it is absurd to imagine that Congress would implicitly grant the courts authority effectively to repeal such legislation. The exercise of such authority would render pointless the entire legislative process.

The fact that Congress theoretically could delegate to the courts the power to modify otherwise unlimited legislation, however, does not mean that Congress has actually done so. It is this improper leap from theoretical possibility to assumed fact that ultimately undermines any defense of the partial abstention model from a separation-of-powers attack. At the very least, the separation-of-powers principle should be deemed to impose a heavy burden of proof on one who would assert that a legislative body implicitly intended to allow the judiciary to amend unlimited legislation. ${ }^{42}$ There is no reasonable basis, in terms of either democratic theory or the realities of the legislative process, for reversing the presumption and concluding that the partial abstention model should fall only if an affirmative case can be made that Congress did not intend such a power to be exercised. When a legislative body enacts legislation, one must assume, absent strong countervailing evidence, that that body intended the courts to perform neither more nor less than their traditional function in a constitutional democracy - to interpret the language and intent of the statute, to

41. One might argue that even if such a delegation had been clearly intended, it would violate the principle of separation of powers, since it would amount to an abdication of authority by the representative branches of government.

42. For example, in the face of silence in the legislative history, the Court will not infer a congressional intent to allow the federal judiciary to develop a private cause of action not expressly authorized in the statute. In making a determination of whether to infer a private cause of action in the face of congressional silence, the courts must examine, inter alia, whether "there [is] any indication of legislative intent, explicit or implicit, either to create such a remedy or to deny one" and whether such an inference is "consistent with the underlying purposes of the legislative scheme to imply such a remedy for the plaintiff . . . " Cort v. Ash, 422 U.S. 66, 78 (1975). The Court has stated that in making this determination, "our task is limited solely to determining whether Congress intended to create the private right of action. . . . And as with any case involving the interpretation of a statute, our analysis must begin with the language of the statute itself." Touche Ross \& Co. v. Redington, 442 U.S. 560, 568 (1979). In California v. Sierra Club, 451 U.S. 287 (1981), holding that $\S 10$ of the Rivers and Harbors Appropriation Act of 1899 did not imply a private cause of action, the Court noted that "there is no "indication of legislative intent, explicit or implicit, either to create such a remedy or to deny one" (citing Cort v. Ash, 422 U.S. at 78) and therefore that "[t]his silence on the remedy question serves to confirm that in enacting the Act, Congress was concerned not with private rights but with the Federal Government's ability to respond to obstructions on navigable waterways." 451 U.S. at 295-96 (footnote omitted). 
enforce it as so construed, and to invalidate or ignore it only when they find that the law is unconstitutional. While there exist several conceivable separation-of-powers defenses for some or all elements of the partial abstention model, all of which derive ultimately from some concept of implied legislative authorization, none of them meets the heavy burden of proof that the separation-of-powers principle demands.

\section{Defenses of the Partial Abstention Model}

Before detailing and critiquing the conceivable justifications for partial abstention, it is important to clarify the distinctions among the variations of the model. Two forms of partial abstention, Pullman and Younger, ${ }^{43}$ are limited in their application to cases involving a federal constitutional challenge to state action. But beyond this link, these two variants differ in several respects. Most important for a separation-of-powers analysis is that Pullman abstention, unlike Younger abstention, does not preclude the exercise of lower federal court jurisdiction; it merely delays it. ${ }^{44}$ For this reason, Pullman abstention might be deemed less of a judicial undermining of the congressional jurisdictional structure. On the other hand, since the Court has traditionally limited Younger to situations in which a federal court is asked to disrupt an ongoing state judicial proceeding, ${ }^{45}$ this form of abstention may arguably be justified by the long tradition of congressional disdain for federal court disruption of state judicial proceedings, ${ }^{48}$ a justification not available for Pullman abstention. Some forms of partial abstention, such as Colorado River abstention for parallel state proceedings, may apply to any type of federal jurisdiction, while still others apply only to the diversity grant.

Although advocates of partial abstention have not attempted to categorize and synthesize the defenses of partial abstention, that task is an important one. Gertain conceivable justifications are limited to a particular

43. See discussion infra pp. 91-95.

44. Pursuant to England v. Louisiana State Bd. of Medical Examiners, 375 U.S. 411 (1964), the federal court may reserve jurisdiction, and decide the federal issue once the state courts have definitively interpreted the state law. However, several commentators have urged that Pullman abstention be modified so that the entire case could be shifted to the state court, instead of returning to the federal court for an adjudication of the federal issue after the state court has decided the meaning of the state law. See, e.g., American LAw INSTTtute, Study of THE Division of JuRisdiction Between STate aND Federal Courts 49, 285-86 (1969) (proposed statutory rejection of England); Kurland, Toward a Co-Operative Judicial Federalism: The Federal Court Abstention Doctrine, 24 F.R.D. 481,489 (1959) (urging that state court be allowed to decide both federal and state questions).

45. Steffel v. Thompson, 415 U.S. 452,461 (1974).

46. See generally 28 U.S.C. $\$ 2283$ (1982) (prohibiting injunctions against state court proceedings except when authorized by Act of Congress or necessary to aid federal court's jurisdiction or enforcement of judgments); Redish, The Anti-Injunction Statute Reconsidered, 44 U. CHI. L. REv. 717 (1977) (examining decisions interpreting 28 U.S.C. $\S 2283$ (1982)). 
form of abstention, while others may apply to all forms. One category of arguments has been used to justify one or more of the forms of partial abstention in cases presenting a constitutional challenge to state action. This category includes (1) the general implied delegation argument (employed to justify any and all forms of partial abstention in such cases); (2) the argument from equity (a specific subset of an implied delegation rationale); and (3) the non-preclusive nature of Pullman abstention.

A fourth justification, which I label the "safety valve" rationale, could conceivably apply to any form of partial abstention, though it soon becomes clear that the argument provides stronger support for some forms than for others. Simply put, this justification-also a variant of an implied delegation rationale-posits that Congress could not possibly have intended the catastrophic social and political effects that would result if partial abstention were not employed. In one case, Parratt $v$. Taylor, a substantive constitutional analysis was applied to justify what was ultimately a jurisdictional decision. Finally, there is the general implied delegation rationale applied specifically in the diversity context. While the institutional arguments about finding an implied delegation in this context are the same as in the case of civil rights jurisdiction, the practical differences are so substantial that I have chosen to distinguish this specific use of the implied delegation rationale from its application to the civil rights context.

Ultimately, none of these rationales successfully defends the partial abstention model against a separation-of-powers attack. As the following discussion will demonstrate, no rationale overcomes the strong presumption against the concept of implied delegation.

\section{A. The Implied Delegation Rationale in Constitutional Challenges to State Action}

One might argue that federal court jurisdiction to enforce federal constitutional rights contains an implied authority to modify or limit the exercise of that jurisdiction in order to avoid friction within the federal system. Congress cannot foresee all conceivable federalism tensions that might arise in specific exercises of federal jurisdiction, the argument would proceed, and therefore it is reasonable to assume that Congress would allow the federal courts to modify or limit their jurisdiction when they find such dangers. It is indeed not uncommon for Congress to provide broad delegations of authority to the federal judiciary to make law. In Textile Workers Union v. Lincoln Mills, ${ }^{47}$ for example, the Supreme Court held that what seemed to be merely a broad jurisdictional statute ${ }^{48}$ vested in the federal

47. 353 U.S. 448 (1957).

48. The relevant statute was $\S 301$ (a) of the Labor Management Relations Act of 1947, ch. 120, 


\section{Abstention}

courts the power to develop-wholly without congressional guidance-a substantive federal common law of labor relations. Similarly, the broad language of section 1 of the Sherman $\mathrm{Act}^{49}$ has been construed as an effective delegation of legislative authority to the judiciary to develop a common law of restraint of trade. ${ }^{60}$ Moreover, the implied delegation argument asserts, if Congress were unhappy with any existing form of partial abstention, it would legislatively revoke it. The failure to do so, combined with reenactment of the relevant substantive and jurisdictional legislation, ${ }^{81}$ the argument posits, reveals an implicit congressional acceptance and ratification of such judge-made limitations.

This argument fails for several reasons. In light of the long history of congressional interest in the tensions of judicial federalism, the basic premise of implied delegation is dubious. Since the nation's beginning, Congress has statutorily dictated federal court abstention whenever it has found federal judicial action to present a danger to the federal system. The Anti-Injunction Act, ${ }^{82}$ the Three-Judge Court Act, ${ }^{53}$ the statutory branch of the habeas corpus exhaustion requirement, ${ }^{54}$ the Tax Injunction Act, ${ }^{\mathrm{BS}}$ and the Johnson Act ${ }^{\mathrm{sB}}$ constitute a statutory network of legislatively directed limitations on the exercise of federal court power to disrupt state proceedings or interfere unduly with state policies.

It is true that the existence of this program of statutorily dictated abstention does not necessarily preclude Congress from vesting in the federal judiciary the authority to extend abstention beyond these legislative limitations. But it does establish that federal court abstention is not an area in which Congress has traditionally deferred to judicial discretion: Congress has long manifested concern with the issue, ordering abstention when it deemed abstention appropriate.

More importantly, the general implied delegation argument suffers from a fatal lack of evidentiary support. No supporter of partial abstention has pointed to anything approaching hard evidence in the legislative

61 Stat. 136, 156 (codified as amended at 29 U.S.C. $\S 185$ (1982)).

49. 15 U.S.C. $\$ 1$ (1982) provides in relevant part: "Every contract, combination in the form of trust or otherwise, or conspiracy, in restraint of trade or commerce among the several States, or with foreign nations, is declared to be illegal . ..."

50. See, e.g., Standard Oil v. United States, 221 U.S. 1, 50-62 (1911); Northern Sec. v. United States, 193 U.S. 197, 404 (1904) (Holmes, J., dissenting); see also National Soc'y of Professional Eng'rs v. United States, 435 U.S. 679, 688 (1978) (It is "perfectly clear" that Congress "expected the courts to give shape to ... [the Sherman Act's] broad mandate by drawing on common-law tradition.").

51. The most recent recodification came in 1948. Act of June 25,1948 , Pub. L. No. 773 , ch. 646, 62 Stat. 932.

52. 28 U.S.C. $\S 2283$ (1982).

53. 28 U.S.C. $\$ 2284(1982)$.

54. 28 U.S.C. $\S 2254$ (b) (1982).

55. 28 U.S.C. $\$ 1341$ (1982).

56. 28 U.S.C. § 1342 (1982). 
history of either the original enactment or the more recent reenactments of the substantive and jurisdictional civil rights statutes which suggests that Congress intended that the federal courts possess authority to modify or limit otherwise unlimited legislation. This failure is not surprising, since there were virtually no references made, in either the debates or committee reports of the 1948 revision of the judicial code, to the scope of jurisdiction under section 1343.57

It is true that Congress has never overruled any judge-made form of abstention, but the argument that a legislative failure to reverse judicial action necessarily implies tacit legislative authorization for that practice is neither theoretically legitimate nor practically realistic. On a theoretical level, it is improper to transform a congressional failure to legislate into the equivalent of legislation. Before legislation is enacted, it must proceed through a detailed and rigorous substantive inquiry, investigation, debate, and formal review in both houses of Congress. This process is, in large part, mandated by the Constitution. The same cannot be said of a failure to legislate.

Moreover, reliance on a congressional failure to overrule a limiting judge-made doctrine, even in a recodification, effectively condones through legislative inertia what was initially an improper and unauthorized judicial usurpation of legislative authority. This breach of separation of powers is thus improperly bootstrapped into the status of legislation. Such an approach, which effectively rewards past and encourages future judicial encroachments upon the legislative province, must be rejected. If Congress intends to condone such judicial action, it should be required to say so expressly in the recodification. At the very least, one should require a clear showing in the legislative history of congressional awareness and acceptance of the judicial action. No such evidence has been cited for the forms of partial abstention. ${ }^{88}$

57. The House report made only brief reference to $\S 1343$, and the Senate report made no reference to it. H.R. Rep. No. 308, 80th Cong., 1st Sess. 1, A121 (1947); S. ReP. No. 1559, 80th Cong., 2d Sess. 1 (1948).

58. It is in part on this basis that the decision in Merrill Lynch, Pierce, Fenner \& Smith v. Curran, 456 U.S. 353 (1982), may be distinguished from my separation-of-powers critique of judgemade abstention. In Merrill Lymch, the Court inferred a private cause of action from the Commodity Exchange Act, 7 U.S.C. $§ 1$ (1982), which was silent on the question. The Court noted that:

[p]rior to the comprehensive amendments to the CEA enacted in 1974, the federal courts routinely and consistently had recognized an implied private cause of action on behalf of plaintiffs seeking to enforce and to collect damages for violation of provisions of the CEA on rules and regulations promulgated pursuant to the statute... . [T] he fact that a comprehensive reexamination and significant amendment of the CEA left intact the statutory provisions under which the federal courts had implied a cause of action is itself evidence that Congress affirmatively intended to preserve that remedy.

456 U.S. at 353, 381-82 (footnotes omitted). Thus, at least in part, the Court based its finding of an implied private cause of action on Congress' failure to revoke the judicially recognized cause of action. If this were the only evidence available to the Court, I would have to reject its analysis as a violation 
On a more practical level, as my colleague Thomas Merrill has argued:

The argument based on the possibility of congressional override ignores the institutional reality that, given its crowded agenda, Congress is far more likely not to act than to act with respect to any particular issue presented for its attention. Thus, the theoretical possibility of congressional override cannot disguise the fact that lawmaking by federal courts would in most cases result in the federal courts, rather than Congress, having the last say. In practice, therefore, institutionalization of the practice of lawmaking by federal courts would represent a major shift in policymaking power away from Congress toward the federal judiciary-in violation of the constitutional scheme. ${ }^{\text {sg }}$

Ironically, one of the best known of the Supreme Court's opinions expressing a separation-of-powers concern about federal judicial lawmaking was written by a staunch advocate of judge-made abstention, Justice Rehnquist. In Milwaukee $v$. Illinois, ${ }^{60}$ he wrote:

Nothing in this process [of formulating federal common law] suggests that courts are better suited to develop national policy in areas governed by federal common law than they are in other areas, or that the usual and important concerns of an appropriate division of functions between the Congress and the federal judiciary are inapplicable. ${ }^{\text {B1 }}$

Although the Court in general and Justice Rehnquist in particular have expressed serious concern about federal judicial encroachment upon the legislative province by the creation of federal common law and have been hesitant to find an implied congressional delegation of lawmaking

of separation of powers. However, the Court also referred to various direct congressional actions and to specific legislative history manifesting congressional awareness of-and desire not to alter-the judicially recognized private cause of action. Such evidence, never cited in support of judge-made abstention, at least presents a closer question in terms of separation of powers. Moreover, the two situations can also be distinguished because the private cause of action recognized in Merrill Lynch could only strengthen the congressional scheme to prevent violations of the CEA. Judge-made abstention, on the other hand, can serve only to undermine achievement of Congress' goals. This factor alone may legitimately dictate the need for a considerably stronger showing of legislative acquiescence before the judiciary should be deemed authorized to depart from the explicit statutory structure.

In any event, it is worthy of note that Chief Justice Burger and Justices Powell, Rehnquist, and O'Connor-generally the leading advocates of judge-made abstention-dissented in Merrill Lynch. Justice Powell's dissent, in which the others joined, argued that the majority's "theory is incompatible with our constitutional separation of powers, and in my view it is without support in logic or in law." 456 U.S. at 395 . If the four Justices applied the same rigorous analysis to the issue of judge-made abstention, they would be required to alter drastically their support of such judicial power.

59. Merrill, supra note 33 , at 28 (footnotes omitted).

60. 451 U.S. 304 (1981).

61. Id. at 313 . 
power, ${ }^{62}$ neither has seen precisely the same dangers inherent in the development of judge-made abstention.

To the extent that there are differences between judge-made abstention and judicial creation of federal common law, the former will usually constitute a greater departure from accepted separation-of-powers principles. To be sure, when a federal court provides a private cause of action for a legislative violation where Congress has intended no such result, there are arguably serious separation-of-powers problems raised. But a far greater judicial encroachment upon the legislative prerogative takes place when the federal courts directly undermine enforcement of an existing legislative program by declining to enforce federal rights in situations not authorized by Congress. Judge-made abstention, then, constitutes judicial lawmaking of the most sweeping nature. The principle of separation of powers would be better protected by the Court's application of the same cautious scrutiny used to review the creation of federal common law to the development of judge-made abstention.

Professor Bator contends that "[t]he Supreme Court has, quite correctly, always taken the position that the post-Givil War jurisdictional and remedial statutes, with their generative language and their complex and multifaceted legislative histories, are essentially open-textured, leaving much to interpretation in light of contexts and postulates not always visible on their surface."Bs Bator's view is both puzzling and vague. Why should these jurisdictional and remedial statutes be deemed any more "open-textured" than any other? The language of the relevant statutes leaves no room for judicial limitation or modification-certainly no more so than the language of other jurisdictional statutes. ${ }^{64}$ Moreover, the very purpose of this legislation was to interpose the federal judiciary between the state and individual, largely because of concern about the functioning of state judiciaries. ${ }^{68}$ If an implied delegation argument is to survive a separation-of-powers challenge, then it must have a firmer basis in fact than Professor Bator has provided.

\section{B. The Argument from Equity}

An implied delegation argument based on equity has been suggested as justification for both Younger and Pullman abstention. However, the argument fails to support either.

In one of the rare instances in which a supporter of judge-made absten-

62. Spe supra notes $42,58$.

63. Bator, The State Courts and Federal Constitutional Litigation, 22 WM. \& MARY L. REv. 605,622 n.49 (1981).

64. See 28 U.S.C. § 1343 (1982); 42 U.S.C. § 1983 (1982).

65. See sources cited supra note 5 . 
tion has even acknowledged the possibility of a separation-of-powers problem, Professor Bator argued that development of such abstention

is the correct enterprise not only because this is institutionally the "correct" or "best" solution, but also because it seems to me to be the proper interpretation of the governing authoritative statutes. . . . Statutes such as $\S 1983$ and the Habeas Corpus Act use language which, if woodenly and anachronistically read, can be interpreted to provide an "absolute" right of access to the federal courts. But these statutes were themselves passed against the background of a large body of standing law on matters of substance, remedy, and jurisdiction. ... The fact that a given remedial doctrine is not explicitly mentioned therefore does not automatically mean that the new statute was intended wholly to supersede it. Thus, to give an example, it seems to me implausible to assume that the cause of action created by and the jurisdiction granted in the Civil Rights Act of 1871 were meant wholly to supersede the preexisting equity doctrine that a good faith criminal prosecution will not ordinarily be enjoined simply because the plaintiff asserts that he has a valid defense to it. ${ }^{66}$

This is a form of an implied delegation argument, but it is, in theory at least, a considerably more disciplined and defensible one than the general implied delegation theory. Section 1983 provides that culpable defendants "shall be liable to the party injured in an action at law, suit in equity, or other proper proceedings for redress." corporates preexisting limitations on the use of equitable power. One could plausibly argue that Younger abstention accords with legislative will because equity would not traditionally enjoin a good-faith criminal prosecution where the defendant had an adequate remedy at law.

There are problems with Professor Bator's analysis, however. The accepted limitation on equitable relief against a criminal prosecution derived from an English unitary system, and therefore the limit on federal equitable power, was traditionally confined to prosecutions in the federal courts. $^{68}$ The principle did not extend to preclude federal interference

66. Bator, supra note 63 , at 622 n.49.

67. 42 U.S.C. $§ 1983$ (1982) (emphasis added).

68. Professor Bator's earlier work acknowledged this fact. P. BAtor, P. Mishkin, D. ShaPIRo \& H. Wechsler, Hart \& Wechsler's The Federal Courts and the Federal System 1009 (2d ed. 1973). See also Whitten, Federal Declaratory and Injunctive Interference with State Court Proceedings: The Supreme Court and the Limits of Judicial Discretion, 53 N.C.L. REv. 591, 637-38 (1975) (criticizing use of English equity principles in the federal courts).

Justice Black also conceded this limitation. After acknowledging the equitable basis for the doctrine of federal court restraint, he noted that "[t]he doctrine may originally have grown out of circumstances peculiar to the English judicial system and not applicable in this country . . . " Younger, 401 U.S. at 44 . It is true that he completed the sentence by stating, "but its fundamental purpose of restraining equity jurisdiction within narrow limits is equally important under our Constitution, in order to prevent erosion of the role of the jury and avoid a duplication of legal proceedings and legal sanctions 
with state court proceedings. In light of this, it is unreasonable to impute to the enacting Congress the understanding that the equitable relief that they were providing would not be used against ongoing state prosecutions. Moreover, because the drafters of section 1983 were especially concerned with the good faith of the state courts, it is unlikely that they assumed that the ability to raise a federal defense in state court constituted an adequate remedy.

The assertion that the statutory provision of equitable relief incorporates traditional equitable limitations logically implies that a federal court may decline to issue a preliminary injunction if it fails to find a likelihood of success on the merits or may deny permanent injunctive relief if a damage remedy adequately protects the plaintiff's interests. But it does not follow that a federal court may appropriately decline to award equitable relief on grounds unrelated to traditional equitable concepts. Younger abstention is based more on considerations of comity and federalism than on traditional grounds of equity. ${ }^{69}$ Because these considerations represent merely the Supreme Court's social judgment about the relative competence of state and federal courts or about the harm caused by federal review of state policies, they are illegitimate judicial incursions into an area where Congress has already spoken.

The Anti-Injunction Act ${ }^{70}$ complicates the equity argument employed to justify Younger abstention. That statute provides: "A court of the United States may not grant an injunction to stay proceedings in a State court except as expressly authorized by Act of Congress, or where necessary in aid of its jurisdiction, or to protect or effectuate its judgments." A federal court may not enjoin a state proceeding unless the injunction falls within one of the three exceptions. The statute does not, however, resolve the separation-of-powers problems posed by Younger, and the Court's express analysis in Younger demonstrates that it did not rely on the Act.

In Younger, the Court found the injunction improper, purely as a matter of judge-made principles. It expressly declined to consider whether the injunction was barred by the Anti-Injunction Act. One year later in Mitchum $v$. Foster, ${ }^{71}$ the Court, in a highly questionable opinion, ${ }^{72}$ found that section 1983 constituted an implied yet "expressly authorized" con-

where a single suit would be adequate to protect the rights asserted." Id. However, such a response fails to consider the issue from the perspective and understanding of the Congress that originally authorized equitable relief for violations of federal rights.

69. See Soifer \& Macgill, The Younger Doctrine: Reconstructing Reconstruction, 55 TEx. L. REv. 1141, 1189 (1977) ("The systemic emphasis of the Younger doctrine deletes the individual concern of equity from the calculus.").

70. 28 U.S.C. $\S 2283$ (1982).

71. 407 U.S. 225 (1972).

72. In another article I have argued that the Mitchum analysis is illogical and inconsistent with both Younger and the statutory language. Redish, supra note 46, at 733-39. 
gressional exception to the Anti-Injunction Act. It nevertheless continued to adhere to the terms of Younger's judge-made abstention doctrine. ${ }^{73}$ In what may be one of the most bizarre contortions of Supreme Court analysis, the Court in Mitchum found section 1983 to be an "implied" express exception (an oxymoron if ever there was one) because of the grave mistrust of the state judiciaries expressed by the drafters of the statute. ${ }^{74}$ Yet Younger rests largely on the desire to avoid insulting state judiciaries by questioning their competence or good faith. ${ }^{75}$

One could reasonably reject Mitchum as a poorly reasoned construction of the "expressly authorized" exception to the Anti-Injunction Act. Younger abstention, at least to the extent it is applied to bar injunctions of ongoing state proceedings, ${ }^{76}$ could conceivably then be viewed as an application of the Anti-Injunction Act. Such a conclusion would logically lead to the abolition of the narrow exceptions to Younger abstention, ${ }^{77}$ but as so modified (in fact, expanded) the doctrine would be insulated from a separation-of-powers critique. Even if the Mitchum analysis were rejected, however, there remains at least an arguable construction of the AntiInjunction Act that could justify most of the injunctions that Younger bars. $^{78}$

73. 407 U.S. at 243.

74. Proponents of the Civil Rights Act of 1871 , the predecessor of $\S 1983$, believed "that state courts were being used to harass and injure individuals ...." Id. at 240.

75. For example, in explicating Younger, the Court has emphasized the need to avoid the "unseemly failure to give effect to the principle that state courts have the solemn responsibility, equally with the federal courts 'to guard, enforce, and protect every right granted or secured by the Constitution of the United States . . . ." Steffel v. Thompson, 415 U.S. 452, 460-61 (1974) (quoting Robb v. Connolly, 111 U.S. 624, 637 (1884)). See also Huffman v. Pursue, Ltd., 420 U.S. 592, 604 (1975) (federal judicial interference with state court nuisance litigation would be "an offense to the State's interest"). Professor Bator has urged that "we should devote serious and sustained attention to protecting and improving the conditions which determine whether constitutional claims are hospitably adjudicated in state courts. This is a more fruitful enterprise than the channeling of more and more cases from the state courts to the federal courts." Bator, supra note 63 , at 629 .

76. Several commentators have urged that Younger be extended to situations in which a state enforcement proceeding is merely contemplated. See Bator, supra note 63, at 616-21; Whitten, supra note 68. The Anti-Injunction Act, however, is applicable only when there is an ongoing state proceeding. Dombrowski v. Pfister, 380 U.S. 479, 484 n.2 (1965).

77. These exceptions include prosecutions filed in bad faith, multiple prosecutions for purposes of harassment, and blatantly unconstitutional state statutes. For a discussion of these exceptions, see $M$. REDISH, supra note 1, at 304-07.

78. In my earlier writing on the Anti-Injunction Act, I argued that the "in-aid-of-jurisdiction" exception should receive a broader construction than the courts have given it. Properly construed, the exception would vest in the federal district court discretion to enjoin a parallel state proceeding, the outcome of which might significantly interfere with the federal court's meaningful exercise of its jurisdiction. Redish, supra note 46, at 743-60. Thus,

[i]f, in addition to seeking an injunction, the federal complaint [under $§ 1983$ ] also seeks a declaration of the federal rights being adjudicated in the state proceeding, the requirement that the federal court possess jurisdiction to be aided is met so long as the declaratory judgment request is cognizable in federal court. The free exercise of jurisdiction to render the declaratory judgment might be impeded substantially by the operation of collateral estoppel if the state proceeding concludes first.

Id. at 759 (footnote omitted). If courts adopt my approach, the "'in-aid-of-jurisdiction' exception 
If, on the other hand, one accepts the logic of the Mitchum holding-as the Court presumably does when it expands the reach of Younger abstention $^{79}$ - then the equity argument fails to justify Younger abstention. The primary purpose of the Anti-Injunction Act is to limit potential friction between state and federal courts. ${ }^{80}$ If Congress intended section 1983 to be an exception to the statute's bar, then presumably Congress decided that the dangers of increased federal-state friction are outweighed by the need to enforce the federal rights guaranteed by section 1983. It is inconceivable that Congress would vest in the federal judiciary total discretion to overrule the product of the congressional balancing process.

One might counter that Congress decided to grant the federal judiciary the discretion to reach a different result in individual cases not foreseen by Congress. But Younger represents considerably more than judicial discretion to restrike the balance in individual cases. Qualified only by a narrow set of rarely-used exceptions, ${ }^{81}$ Younger abstention is all but total. ${ }^{82}$ Thus, if Mitchum is valid, Younger abstention represents an effective reversal of the congressional decision to make section 1983 an exception to the AntiInjunction Act. In any event, even if Younger abstention were to take the form of an individualized, case-by-case analysis, in light of Mitchum a separation-of-powers analysis of judicial lawmaking requires that such a practice be justified by convincing evidence in the legislative history (of either the Anti-Injunction Act or section 1983). No one has ever suggested that such evidence exists.

In sum, the combined effect-if not the motivation-of the Court's decisions in Younger and Mitchum is that the federal judiciary has arrogated to itself the authority to decide when to enjoin state court proceedings. It is difficult to imagine a starker illustration of judicial usurpation of legislative authority. To the extent that Younger is viewed as a judge-made

might achieve many of the results reached by the Mitchum approach . . . while avoiding many of the problems generated by the Mitchum approach." Id. (footnote omitted).

79. See, e.g., Moore v. Sims, 442 U.S. 415 (1979) (pending civil proceeding); Trainor v. Hernandez, 431 U.S. 434 (1977) (ongoing civil enforcement action).

80. See Hale v. Bimco Trading, Inc., 306 U.S. 375, 378 (1939) (Frankfurter, J.) (The statute "is an historical mechanism . . . for achieving harmony in one phase of our complicated federalism by avoiding needless friction between two systems of courts having potential jurisdiction over the same subject-matter."); Redish, supra note 46 , at 718 .

81. See Redish, supra note 5 , at $473-74$.

82. As Soifer and Macgill have observed:

The considerations of equity and comity developed through decades by the Court to accommodate the tensions among state power, federal power, and individual rights, have been turned into a single, rigid commandment of federal judicial inaction that violates even such rules as equity and comity could be said to have contained. As the Court declared recently, "where a case is properly within [the scope of the Younger doctrine], there is no discretion to grant injunctive relief." [quoting Colorado Water Conserv. Dist. v. United States, 424 U.S. 800, 816 n.22 (1976).] This rigidity has eliminated the discretionary balancing at the heart of equity. Soifer \& Macgill, supra note 69, at 1143 (footnote omitted) (brackets in original). 
doctrine, then, it cannot be rationalized on the basis of traditional equitable principles.

Equitable principles do not justify Pullman abstention any more than they explain the Younger doctrine. In Pullman, Justice Frankfurter attempted to rationalize that form of judge-made abstention as a traditional exercise of the judiciary's equitable powers:

In this situation a federal court of equity is asked to decide an issue by making a tentative answer which may be displaced tomorrow by a state adjudication. ... The resources of equity are equal to an adjustment that will avoid the waste of a tentative decision as well as the friction of a premature constitutional adjudication.

An appeal to the chancellor .... is an appeal to the "exercise of the sound discretion, which guides the determination of courts of equity." .. . The history of equity jurisdiction is the history of regard for public consequences in employing the extraordinary remedy of the injunction. . . . Few public interests have a higher claim upon the discretion of a federal chancellor than the avoidance of needless friction with state policies .... This use of equitable powers is a contribution of the courts in furthering the harmonious relation between state and federal authority without the need of rigorous congressional restriction of those powers. ${ }^{83}$

This resort to equity fails to rationalize Pullman abstention. Initially, the doctrine has never been limited to cases in which equitable relief is sought. ${ }^{84}$ More importantly, Justice Frankfurter's reliance on equitable principles as a means of avoiding friction within the federal system amounts to an historical non-sequitur. As previously noted, ${ }^{85}$ the doctrine of equity was developed in England, which knows no federal structure. One may reasonably wonder, then, how Justice Frankfurter could assert that the doctrine of equity can serve as a vehicle for the judicial accommodation of federalism concerns.

The most puzzling aspect of Justice Frankfurter's analysis is the assertion that a federal court's equity powers allow it to take account of federalism concerns "without the need of rigorous congressional restriction of those powers." allow the federal courts to limit themselves, so that Congress need not do so. But, as already noted, Congress has limited federal judicial power when it deemed such limitation necessary to protect federalism interests.

83. 312 U.S. at 500-01.

84. See, e.g., Fornaris v. Ridge Tool Co., 400 U.S. 41 (1970) (per curiam); United Gas Pipe Line Co. v. Ideal Cement Co., 369 U.S. 134 (1962) (per curiam).

85. Sep discussion supra p. 85.

86. 312 U.S. at 501 . 
The Anti-Injunction Act is one example. There is thus no basis for inferring such an implied delegation of congressional authority to the federal courts. ${ }^{87}$

\section{The Unique Impact of Pullman Abstention}

The unique nature of Pullman abstention suggests an arguable means of rationalizing it with separation-of-powers. While all other forms of partial abstention in some sense preclude, or at least have the potential of precluding, federal court adjudication, Pullman abstention does nothing more in theory than delay federal adjudication. Under the terms of this form of abstention, the federal court simply gives the state courts an opportunity to provide a definitive construction of an ambiguous state statute's meaning. However, if the plaintiff so indicates, he may reserve the opportunity to return to federal court for the adjudication of the federal issue once the state court has definitively construed the state law. ${ }^{88}$ In a sense, then, Pullman abstention may be deemed not to undermine separation-of-powers principles, because it does not actually preclude the exercise of federal court jurisdiction.

But even a delay in the exercise of federal jurisdiction may be considered a violation of separation of powers if it has not been contemplated by Congress. ${ }^{88}$ Conceptually, a delay of federal adjudication constitutes a modification of the statutory structure, much as a preclusion under narrowly defined circumstances may. The difference is merely one of degree. Moreover, invocation of Pullman abstention may, as a practical matter, so severely delay the exercise of federal jurisdiction that it acts as a significant deterrent to the resort to federal court.90

\section{The "Safety Valve" Rationale}

The final means of attempting to justify most forms of partial abstention is the so-called "safety valve" rationale. Under this theory, partial abstention is allowed, despite the absence of express congressional authorization, because the social and political results of an abolition of abstention would be so disastrous that Congress could not possibly have contemplated them. In a sense, this analysis represents a form of the "clear statement"

87. Justice Frankfurter's comment is even more puzzling in light of the fact that his statement was followed by a citation to the existing form of the Anti-Injunction Act. Id.

88. See England v. Louisiana State Bd. of Medical Examiners, 375 U.S. 411, 418 (1964).

89. The Supreme Court recognized this fact in rejecting the requirement of exhaustion of state administrative remedies for $\S 1983$ suits in Patsy v. Board of Regents, 457 U.S. 496 (1982).

90. See Field, supra note 1 , at 1087. 


\section{Abstention}

rule of statutory construction: Unless Congress has expressly and inescapably said so, the courts will not construe a statute to reach such a result. ${ }^{\text {91 }}$

Before discussing the merits of this theory, it is necessary to underscore the limited nature of the inquiry authorized by such a rationalization. Under separation-of-powers principles, the inquiry cannot amount to an argument over whether, as a matter of social policy, federal abstention represents the wiser course. The "safety valve" rationale for judge-made abstention is a variation on the implied delegation argument, an argument that should not be employed freely, lest the judgments of the electorally accountable legislature be too easily circumvented by the judiciary. In fact, one could persuasively argue that no matter how disastrous the social results, unless the courts can find substantial and convincing support in the legislative history for a finding of implied delegation, none should be found.

It is not necessary to rely on this analysis to reject the "safety valve" rationale, however, because it is clear that the harms prevented by the abstention doctrines are not so overwhelming as to be disastrous, and many could be avoided more simply by resort to such devices as legitimate statutory construction and traditional equitable principles. The abstention doctrines create more harm than they avoid.

\section{Younger Abstention}

The social policy harms thought to be avoided by Younger abstention include the fear that state judges will be insulted by the doubts raised about their competence to enforce federal rights, ${ }^{92}$ that state executive and legislative policies will be undermined by federal rather than state adjudication of their constitutionality, ${ }^{93}$ and that federal injunctions of ongoing state judicial proceedings will unduly disrupt the conduct of the state judicial process. ${ }^{94}$

The most puzzling of these rationales is the concern for the judicial treatment of state legislative and executive policies. First, the argument is inconsistent with the initial Younger rationale, that federal injunctions question the traditional assumption that state courts will enforce federal rights as competently and as enthusiastically as federal courts. If it is

91. See Employees of the Dep't of Public Health \& Welfare v. Department of Public Health \& Welfare, 411 U.S. 279, 284-85 (1973). This type of analysis is a form of what Professor Calabresi has described as the "second look" doctrine. G. Calabresi, A Common LAw for the Age of STATUTES 18 (1982).

92. See supra note 75 .

93. See Trainor v. Hernandez, 431 U.S. 434, 443-46 (1977).

94. See Younger v. Harris, 401 U.S. 37, 44 (1971). For a detailed discussion of why, as a matter of social policy rather than separation of powers, I reject these rationales for the sweeping deference dictated by Younger, see Redish, supra note 5. 
thought that state judges, because of their proximity to the local scene, will be more sympathetic to state concerns, ${ }^{95}$ then it is difficult to see how state judges can also be equally enthusiastic enforcers of federal rights against state action.

More importantly, the rationale appears to be premised on a false characterization of federal judges as "carpetbaggers." "86 Like their state counterparts, federal judges generally reside within the state in which they sit. Many have previously served as state judges. Most have had long and distinguished careers practicing law in the state in which they sit. It is therefore difficult to understand why federal, rather than state, adjudication will undermine state legislative and executive interests. The only clear difference between the two is that federal judges are insulated from external state and local political pressures, while state judges generally are not. It is true that this distinction could make a considerable difference in how the two will reconcile competing state and constitutional interests. But it does not follow that we should consider this difference in deciding whether to transfer the decision on constitutionality from state to federal court. If anything, the distinction cuts in favor of transferring the constitutional decision to federal court, since a forum subject to external political pressures from the very political institutions whose conduct is challenged arguably fails to provide the independence required by due process. ${ }^{97} \mathrm{At}$ the very least, we should not allow this difference to cause us to order federal deference to the state processes.

The only conceivably "disastrous" result from abolishing Younger abstention would be the possible disruption of the state judicial process. One could conjure visions of defendants in state prosecutions who, after unsuccessfully challenging the admissibility of evidence on Fourth Amendment grounds, walk across the street to the federal courthouse to seek an injunction of the state proceeding as a violation of section 1983. In this context, a federal injunction would indeed constitute a major disruption of the state judicial process.

Younger abstention, however, is not necessary to avoid this disruption. By its terms, section 1983 authorizes injunctive relief only if a federal right has been violated. Thus, unless an individual has suffered a deprivation of life, liberty, or property, the state officer has not violated the due process clause. In the above hypothetical, a federal court might not issue an injunction, reasoning that no deprivation of the state defendant's liberty resulted from the state court's admission of the challenged evidence. At the earliest, such a deprivation would result when the defendant is

95. See Bator, supra note 63.

96. Sep Neuborne, supra note 14 , at 1128 .

97. I have explored this issue in greater detail in Redish, supra note 15. 


\section{Abstention}

convicted, and perhaps not until he begins serving his sentence. In any event, the relevant point is not the state judge's decision to admit the evidence. Once it is recognized that the deprivation does not occur until some point after the conviction, it is reasonable to construe congressional intent to mean that the Habeas Corpus Act, ${ }^{98}$ which is specifically designed to apply to post-conviction review and which expressly provides for exhaustion of state judicial remedies, ${ }^{99}$ supersedes the more general terms of section 1983. Under section 1983, then, federal injunctions would rarely issue against ongoing state proceedings, since the interlocutory decisions of state judges generally do not themselves constitute deprivations of a constitutionally protected interest.

The primary exception is a situation involving First Amendment rights, as in Younger itself. There the federal plaintiff had been indicted for distributing leaflets alleged to be in violation of the California Criminal Syndicalism Act. He sought a federal Court injunction of the state prosecution on the grounds that the state law violated the First Amendment and that the state prosecution chilled the continued exercise of his free speech rights. If one accepts the "chilling effect" concept (and it has a venerable heritage in the law of the First Amendment), ${ }^{100}$ then under the unique circumstances of a First Amendment violation, the very existence of the prosecution constitutes a deprivation of liberty. As such, it constitutes a violation of section 1983.

In his opinion for the Court in Younger, Justice Black seriously questioned the validity of the "chilling effect" analysis, and doubts about the doctrine are far from frivolous. ${ }^{101}$ These issues are beyond the scope of this Article. The important point for separation-of-powers purposes is that Justice Black did not confine himself to a debate over the efficacy of the "chilling effect" rationale. If he had, Younger could be viewed simply

98. 28 U.S.C. § 2254 (1982).

99. 28 U.S.C. § 2254(b) (1982).

100. The concept relates principally to the First Amendment overbreadth doctrine. See County Court v. Allen, 442 U.S. 140,155 (1979). It has also been relied upon to justify creation of a broad First Amendment privilege for defamation of public officials. New York Times Co. v. Sullivan, 376 U.S. 254, 279 (1964).

101. Justice Black stated that:

this sort of "chilling effect," as the Court [in Dombrowski] called it, should not by itself justify federal intervention. In the first place, the chilling effect cannot be satisfactorily eliminated by federal injunctive relief. . . . The chilling effect can, of course, be eliminated by an injunction that would prohibit any prosecution whatever for conduct occurring prior to a satisfactory rewriting of the statute. But the States would then be stripped of all power to prosecute even the socially dangerous and constitutionally unprotected conduct that had been covered by the statute, until a new statute could be passed by the state legislature and approved by the federal courts in potentially lengthy trial and appellate proceedings.

401 U.S. at 50-51.

Doubts about the doctrine are far from frivolous. See Note, Overbreadth Review and the Burger Courl, 49 N.Y.U. L. REv. 532, 546 (1974) ("Chilling effect decisions are often dependent on the fiction that people are aware of the content of the statutes under which they live."). 
as a substantive constitutional decision: The mere fact of prosecution does not abridge the freedom of speech, nor does it deprive one of liberty without due process. While this conclusion would have been subject to challenge as a matter of First Amendment law and policy, it would not have been so contrived as to be vulnerable to a separation-of-powers critique. But that was not the analysis employed in Younger. Instead, the Court asserted inherent authority to void the implications of a statutory directive. It is, then, the analysis in Younger, rather than its substantive result, that represents a striking departure from separation-of-powers principles.

Even if we were to adopt a "chilling effect" rationale, relatively few state judicial proceedings are likely to give rise to First Amendment challenges. It is conceivable, however, that the very institution of other types of state proceedings could give rise to deprivations of liberty or property. For example, an individual arrested on the basis of illegally seized evidence might reasonably argue that he or she had been deprived of liberty without due process at that very point. If a federal court has been denied authority to employ judge-made abstention, an injunction against prosecution would issue in an appropriate case. But if one believes, as the Court reasoned in Mitchum, that Congress has decided that the increase in intergovernmental friction caused by a federal injunction of a state judicial proceeding is justified by the need for federal judicial protection of federal rights, then this result would have been contemplated by Congress. In any event, if the sole issue presented in the injunction proceeding is the legality, under the Fourth Amendment, of the search and seizure that led to the arrest, no state legislative policies are either interpreted or challenged by a federal court. One might even argue that the state judicial process has been freed from a burden, since a valid federal injunction of the prosecution at the very onset of the state proceeding could save the state the time and expense of conducting a proceeding that will invalidated by a federal court in a subsequent habeas corpus proceeding.

It should be emphasized that a state defendant cannot, on his own, bring to a halt a state judicial proceeding. He must first obtain some form of federal injunctive relief, either preliminary or permanent. In deciding whether to issue such relief in an individual case, a federal court will presumably inquire into the questions traditionally asked in equity analysis. If the federal plaintiff has failed to demonstrate a likelihood of success on the merits or has unduly delayed in seeking equitable relief, the federal court may properly deny such relief. A state defendant thus cannot employ the federal courts simply as a delaying or harassing tactic. It is true that the state may be subjected to the requirements of the discovery process in the federal action. But given the available methods of curbing dis- 
covery abuse, ${ }^{102}$ it is difficult to imagine that this would so burden the resources of the state prosecutor as to fall within the extreme category of exceptions contemplated by the "safety valve" rationale.

\section{Pullman Abstention}

The social purposes thought to be served by Pullman abstention are well known. ${ }^{103}$ Federal courts traditionally attempt to avoid the unnecessary decision of federal constitutional issues, and when the validity of state law is challenged, simple principles of federalism dictate that the federal judiciary avoid invalidating the law under the federal Constitution if at all possible. If federal court abstains pending state judicial construction of a challenged state law, it may not need to reach the issue of the law's constitutionality.

Of course, these goals might be accomplished without resort to Pullman abstention. A federal court that desires to avoid a constitutional confrontation may provide its own narrowing construction of the state statute. However, a federal judicial construction of a state statute is not binding on the state courts. Ideally, the state courts should be given the first opportunity to provide a definitive construction of an ambiguous state statute.

Federal construction of state statutes, however, is by no means uncommon. Federal courts are often called upon to interpret state statutes in the exercise of their diversity jurisdiction. The Supreme Court has rejected the uncertainty of state law as a basis for federal judicial refusal to exercise diversity jurisdiction. ${ }^{104}$ Yet federal judicial constructions of state statutes in the course of the exercise of the diversity jurisdiction are no less difficult or temporary than in the exercise of the jurisdiction over constitutional challenges to state statutes.

The harms caused by resort to Pullman abstention are arguably as great as those which it is designed to avoid. Determining whether a state statute is sufficiently ambiguous to justify resort to Pullman abstention requires a significant amount of judicial time and effort. Pullman abstention may substantially delay the enforcement of federal rights. ${ }^{105}$ Moreover, one may question whether the interests of federalism are furthered by a procedure that effectively employs state courts as little more than research assistants for the federal judiciary. Nevertheless, it is conceivable that on balance an objective policy analysis would dictate the continued use of Pullman abstention. Because the benefits of the doctrine are not so

102. See FED. R. Grv. P. 26(c).

103. See M. REDISH, supra note 1 , at 234-35.

104. Meredith v. City of Winter Haven, 320 U.S. 228, 234 (1943).

105. See Field, supra note 1 , at 1085-86. 
overwhelmingly greater than its harms that reasonable people could not differ over the issue, Pullman abstention cannot legitimately fall within a "safety valve" analysis. The careful weighing of competing social and political policies represented in Pullman abstention is the very function that separation-of-powers principles assign to the legislative branch. Thus, any continued use of Pullman abstention to modify the statutorily unlimited substantive and jurisdictional structure should come from further congressional action, not from judge-made abstention.

\section{Colorado River Abstention}

In Colorado River Water Conservation District v. United States, ${ }^{108}$ the Supreme Court held that while a federal court generally may not decline to exercise its jurisdiction in the face of a concurrent or parallel state proceeding, circumstances justifying such a stay, "though exceptional, do nevertheless exist."107 Justice Brennan's opinion for the Court authorized a federal court to dismiss the proceedings pending before it because of factors which were arguably unique to that case. However, in the subsequent case of Will $v$. Calvert Fire Insurance Co. ${ }^{108}$ four members of the Court joined in an opinion authorizing a stay of federal court proceedings because of the existence of a parallel state action under somewhat broader circumstances. ${ }^{109}$ Justice Rehnquist, writing for the plurality, emphasized the need for a federal trial court's exercise of discretion in such matters:

There are sound reasons for our reiteration of the rule that a district court's decision to defer proceedings because of concurrent state litigation is generally committed to the discretion of that court. No one can seriously contend that a busy federal trial judge, confronted both with competing demands on his time for matters properly within his jurisdiction and with inevitable scheduling difficulties because of the unavailability of lawyers, parties, and witnesses, is not entrusted with a wide latitude in setting his own calendar. ${ }^{110}$

This analysis confuses a district court's authority to control the timing of adjudication with its power to decide whether to exercise its jurisdiction at all. Of course, as a technical matter, in such a case the federal court would merely stay the exercise of its jurisdiction. However, it is disingenuous to construct an analysis on this premise, because a stay of the federal proceeding pending the outcome of a parallel state proceeding will inevitably

106. 424 U.S. 800 (1976).

107. Id. at 818 .

108. 437 U.S. 655 (1978).

109. Id. at 665 .

110. Id. 
lead to the use of collateral estoppel or res judicata to preclude the meaningful exercise of federal court jurisdiction.

The policy justifications for this aspect of the partial abstention model are the interest of the federal courts in docket control and the interest of the litigants in avoiding harassment through the filing of multiple lawsuits. Neither of these concerns, however, rises to a level of social harm so disastrous as to fall within a "safety valve" rationale. The interest in docket control is of limited concern, because the few cases in which (1) a parallel state proceeding exists, and (2) the federal court would for that reason decline to exercise its jurisdiction, are unlikely to have anything more than a marginal impact on the federal courts' dockets. Nor is the risk of multiple litigation substantial enough to authorize judge-made abstention. The danger of such harassment exists only because of the unduly narrow construction of the so-called "in aid of jurisdiction" exception to the Anti-Injunction Act, ${ }^{112}$ which prevents federal courts from enjoining parallel state proceedings when there exists a serious danger of harassment. ${ }^{112}$ The reality of litigation is that parties often attempt to employ various strategic devices in order to impose burdens on each other. While these may give rise to some level of unfairness, it does not follow, absent clear congressional expression to the contrary, that the exercise of federal jurisdiction should be sacrificed to avoid them.

Justice Rehnquist's expansion of the scope of abstention has been significantly reduced by Moses H. Cone Memorial Hospital $v$. Mercury Construction Corp. ${ }^{113}$ There, the Court refused to allow the lower federal court to defer to a parallel state proceeding in a contract dispute, distinguishing Calvert on the ground that the review sought there was by means of mandamus, ${ }^{114}$ while in Moses $H$. Cone it was by direct appeal. ${ }^{115}$ Moreover, the Court added, "to say that the district court has discretion is not to say that its decision is unreviewable; such discretion must be exercised under the relevant standard prescribed by this Court."118 Under the "exceptional circumstances" standard of Colorado River, the abstention was not justified.

Moses $H$. Cone seems to indicate that abstention for parallel state proceedings will be substantially curbed. The possibility of such abstention

111. 28 U.S.C. $\$ 2283$ (1982) provides in relevant part: "A court of the United States may not grant an injunction to stay proceedings in a State court except . . . where necessary in aid of its jurisdiction. ...."

112. See Kline v. Burke Constr. Co., 260 U.S. 226 (1922). The Court distinguishes an action in personam, where subsequent state action could not be prohibited, from actions in rem, where they could. Id. at 229.

113. 460 U.S. 1 (1983).

114. Id. at 938.

115. Id. at 933 .

116. Id, at 938. 
still remains, however, and under the separation-of-powers analysis, even this limited form of abstention cannot be justified.

\section{Burford and Thibodaux Abstention}

By far the least justifiable forms of abstention are the Burford branch for complex state administrative schemes and Thibodaux abstention for important but undefined state interests such as eminent domain. ${ }^{117}$ While there may well be reasons to prefer state adjudication of controversies involving complex state administrative programs, it does not follow that federal adjudication would so substantially interfere with the function of those programs as to justify invocation of a "safety valve" exception to congressionally dictated jurisdiction. It is quite conceivable that an objective policy analysis, wholly apart from separation-of-powers considerations, would justify abandonment of these forms of abstention, because of the difficulties in applying their broad and nebulous criteria to the facts of individual cases. Thus, if competing policy interests are to be balanced in favor of abstention, the concept of separation-of-powers dictates that such a decision should be made by Congress.

\section{E. The Confusion of Jurisdictional and Substantive Constitutional Analysis: Parratt v. Taylor}

In Parratt v. Taylor ${ }^{118}$ the Supreme Court, in an opinion by Justice Rehnquist, held that a prisoner's complaint alleging the negligent loss by prison officials of a hobby kit constituted an actionable "deprivation" of property under section 1983 . The Court, however, reasoned that the claim would be valid only if the prisoner had been deprived of the property without due process of law. The availability of a state tort remedy to compensate a plaintiff for a negligent loss constituted due process, and the plaintiff thus had failed to state a cause of action under section $1983 .{ }^{119}$

It may not, at first glance, be apparent how the decision in Parratt represents a form of judge-made abstention. One might argue that the decision is simply an interpretation of the reach of the constitutional right, and has nothing to do with the allocation of jurisdictional authority between state and federal courts. But an analysis of the Court's reasoning reveals that the decision has the impact of a jurisdictional doctrine in many ways functionally indistinguishable from a judicial exhaustion requirement, ${ }^{120}$ at least in the not uncommon case in which the deprivation

117. M. REDish, supra note 1 , at $240-55$.

118. 451 U.S. 527 (1981).

119. Id. at 544 .

120. Judge Joiner effectively acknowledged as much in Barnier v. Szentmiklosi, 565 F. Supp. 869 
of life, liberty, or property represents an abuse of the state officer's authority. ${ }^{121}$ The Court accomplishes this significant jurisdictional reallocation through its interpretation of the constitutional right sought to be enforced. In this manner, the Court appears to have insulated the doctrine from a separation-of-powers critique: No one would question that it is appropriate for the courts to interpret the meaning of a constitutional provision, and surely there is no undermining of a congressional program of federal judicial enforcement of constitutional rights when the Court decides that no right exists.

Despite the ingenious nature of this jurisdictional sleight of hand, the substantive constitutional analysis required to reach the Court's conclusion is devoid of logic and inconsistent with accepted constitutional precedent. Ultimately, the doctrine amounts to a jurisdictional reallocation, a point on occasion candidly acknowledged by supporters of such a reallocation. ${ }^{122}$ The initial question about Parratt concerns the Court's conclusion that the state officer's negligent loss of a $\$ 24$ hobby kit amounts to a prima facie deprivation of "property" for purposes of the due process clause. ${ }^{123}$ The conclusion is especially puzzling in light of Justice Rehnquist's earlier statement for the Court that libel by a state officer does not constitute a violation of section 1983, in part because to hold that it did would federalize a substantial portion of state tort law. ${ }^{124}$ Certainly, the same could be said of a holding that a state officer's negligence amounts to a constitutional violation. Moreover, Justice Rehnquist had previously held that a three-day false imprisonment did not constitute a deprivation of "liberty"; ${ }^{125}$ it is difficult to understand how he could then conclude that the type of deprivation involved in Parratt could rise to a constitutional level. On the basis of either a common sense de minimis exception or the rea-

(E.D. Mich. 1983), when he stated that "[s]ince state law already provides remedies for injuries such as those suffered by the Barniers, it is wasteful to provide additional remedies. To do otherwise encourages multiple litigation and undesirable forum shopping." Id. at 881 . These considerations are not relevant to the constitutional question of what constitutes due process, but rather to the broad policy issues of jurisdictional allocation.

Parrall exhaustion actually goes further than a direct exhaustion requirement in excluding the exercise of federal jurisdiction, because Parralt effectively excludes Supreme Court review, as well as lower federal court jurisdiction. Whereas under Parratt the Supreme Court could presumably review state procedures for adequacy under the due process clause, the actual application of state tort law to the specific facts would present no federal issues, and would thus fall outside the Supreme Court's jurisdiction.

Justice Rehnquist has, in another context, suggested that the judicial exhaustion requirement should be reconsidered. City of Columbus v. Leonard, 443 U.S. 905, 910-11 (1979) (Rehnquist, J., dissenting from denial of certiorari), discussed infra p. 105.

121. In Logan v. Zimmerman Brush Co., 455 U.S. 422 (1982), the Court limited Parratt to such situations.

122. See Barnier v. Szentmiklosi, 565 F. Supp. at 881 .

123. 451 U.S. at 536-37.

124. Paul v. Davis, 424 U.S. 693,699 (1976).

125. Baker v. McCollan, 443 U.S. 137 (1979). 
soning that negligent conduct does not amount to the type of state conduct at which the Fourteenth Amendment was aimed, the Court could legitimately have excluded the conduct involved in Parratt from the scope of the Constitution.

After reaching that initial and uncharacteristically expansionist conclusion, though, Justice Rehnquist reasoned that this deprivation of property violates the due process clause only if the deprivation is undertaken without due process. ${ }^{126}$ While he acknowledged that the negligent loss took place prior to any hearing, he noted that a post-deprivation hearing sometimes satisfies procedural due process requirements. ${ }^{127}$ Justice Rehnquist concluded in Parratt that there was no violation of due process as long as the state provided a "post-deprivation hearing"-i.e., an adequate tort remedy for damages. ${ }^{128}$

The Court's procedural due process analysis is defective because it attempts to squeeze a square peg into a round hole. The basic assumption of a procedural due process analysis is that the ultimate result-i.e., the loss of property or liberty-is not inherently unconstitutional; it is unconstitutional only if adequate procedures are not followed. For example, welfare benefits may be deemed a property interest sufficient to trigger the requirements of due process, ${ }^{129}$ but as long as the state takes away these benefits only after affording sufficient procedures to determine that the deprivation is justified, there has been no constitutional violation. On the other hand, if the state enacts a law saying all Jews are to be denied governmental benefits, the law's unconstitutionality is not cured by the provision of a full dress pre-deprivation hearing to determine whether the individual in question actually is Jewish; the end result is unconstitutional, regardless of the procedures that are followed. The constitutional defect does not turn on the availability of procedures, and the constitutional issue is therefore not one of procedural due process.

The Court's characterization of Parratt as a procedural due process case is erroneous. The essence of the constitutional deprivation in the context of procedural due process is the loss of a protected interest absent adequate procedure. It is incorrect to suggest that the end result of a negligent loss of a prisoner's property is rendered legitimate and appropriate-like the revocation of welfare benefits-by the provision of proper procedures. One could not, ex ante, validly assert that a state officer's

126. Id. at 537 .

127. A post-deprivation hearing is sufficient, for example, when the need for state action is so immediate and compelling that it is not feasible to provide a predeprivation hearing. Id. at 538. See North American Cold Storage v. City of Chicago, 211 U.S. 306 (1908) (under police power, state may seize and destroy unwholesome food without notice or hearing; owner has right of action afterward).

128. 451 U.S. at 543

129. See Goldberg v. Kelly, 397 U.S. 254 (1970). 
negligent loss of property is acceptable behavior as long as proper procedures are followed. Though of course such negligent loss may be subsequently compensated, the same is true of any illegal behavior. This fact in no way renders the behavior legitimate.

The analysis may be clouded somewhat by the specific facts of Parratt because it is not obvious that a negligent loss of property is any kind of constitutional violation, whether or not accompanied by adequate procedures. The point may be better understood when applied in a wholly different context (one in which a number of lower courts have in fact employed the Parratt analysis ${ }^{130}$ ): the physical beating of an individual by state or local officials. It is difficult to imagine that the end result of a beating could ever be justified by the provision of adequate procedures; the case is more analogous to the discrimination against Jews, than to the removal of welfare benefits, because in neither the beating nor discrimination examples can the end result be "purified" by the use of proper procedures.

If one were to accept Justice Rehnquist's assumption that a constitutional defect in the conduct of state officers may be cured by the provision of a state compensatory tort remedy, even the most egregious and intentional violation of constitutional rights by state officers could be transformed into a "procedural" due process case. Take for example the unjustified police disruption of a political rally and the beating of demonstrators solely because of distaste for the political views expressed. While the officers' conduct may be thought to violate the First Amendment, it is only through the Fourteenth Amendment's due process clause that such state action gives rise to a constitutional violation. However, if the violation of First Amendment rights could be compensated subsequently by state tort remedies, no constitutional violation would have taken place. Once the Court extends the concept of "procedural" due process to include the provision of state compensatory "procedures" for conduct that reaches unconstitutional results, no state action can logically be deemed to violate the due process clause unless and until available state tort remedies have been pursued. ${ }^{131}$ This conclusion distorts the concept of procedural due process into a thinly-veiled creation of a state judicial exhaustion requirement.

130. See, e.g., Rutledge v. Arizona Bd. of Regents, 660 F.2d 1345, 1352 (9th Cir. 1981), affd on other grounds sub nom. Kush v. Rutledge, 460 U.S. 719 (1983); Barnier v. Szentmiklosi, 565 F. Supp. at 876-79.

131. It is true that Justice Rehnquist implied that the due process analysis of Parratt was inapplicable to cases involving violations of the first eight amendments. 451 U.S. at 536. But it is difficult to understand how he can draw this distinction. All of those amendments are made applicable to the states through the due process clause; thus, they involve liberty interests. The inherent assumption of Rehnquist's analysis is that there is no denial of liberty or property until the state refuses to compensate. 
One must recall that "exhaustion" in this context means considerably more than it does in other contexts. Under the concepts of res judicata and collateral estoppel, state court factual findings would be binding in any subsequent federal action, and because state courts possess concurrent jurisdiction with federal courts over section 1983 actions, a plaintiff's failure to join his federal cause of action in his state suit would likely bar a subsequent federal action on grounds of res judicata.

More importantly, under the Parratt analysis, the constitutional violation is not the state officer's initial conduct, but the failure of the state to provide a procedure for a compensatory remedy. Yet by its terms, section 1983 is directed toward the conduct of persons acting under color of state law, not conduct of the state itself. Hence, the logical implication of Parratt is that there can never be a violation of section 1983, at least when the state officer has departed from accepted state practice. Moreover, the Court in no way required that the state actually compensate the plaintiff but merely that the opportunity for compensatory procedures be made available. Thus, the state could deny compensation because of its own factual findings, and under Parratt no constitutional violation would exist. Indeed, such state findings would be insulated from any federal review, even in the Supreme Court. The Court has thus devised a "super" exhaustion requirement that not only effectively precludes lower federal court review of state judicial findings, but precludes Supreme Court review as well.

Parratt appears superficially consistent with the legal process and separation-of-powers concerns that are the focus of this Article. The Court no doubt possesses legitimate authority to interpret the meaning of the Constitution, and theoretically Congress' legislative and jurisdictional schemes for federal judicial enforcement of federal constitutional rights are not undermined when no constitutional right has been violated. But when the Court so clearly distorts the meaning of constitutional provisions in order to achieve a major reallocation of jurisdictional authority not contemplated by the congressional structure, as it has done in Parratt, resort to substantive constitutional analysis cannot insulate the Court from a separation-of-powers critique.

\section{F. Partial Abstention in the Diversity Context}

The federal courts have long refused to exercise diversity jurisdiction over certain types of cases-primarily matters of probate ${ }^{\mathbf{1 3 2}}$ and domestic

132. See Note, Federal Jurisdiction and Practice: Probate Matters, 15 OKLA. L. REv. 462 (1962). 
relations ${ }^{133}$ - that seemingly fall within the terms of their jurisdiction. Originally, the rationale for these two exceptions was framed in terms of statutory construction. Since historically neither of these types of cases would have been heard in the ecclesiastical courts, ${ }^{134}$ both types of cases were thought to fall outside of the diversity jurisdiction statute, which originally applied to "suits of a civil nature in law or in equity." It was additionally suggested that diversity jurisdiction could not extend to suits between husband and wife, because a wife could not have a different residence from her husband. ${ }^{135}$ Today, all of these arguments premised on statutory construction have been abandoned, and it now appears that the exceptions are simply manifestations of judge-made abstention, founded on grounds of social policy. ${ }^{138}$

These forms of partial abstention can be tested under the same standards applied to the other forms. There is no clear indication in the legislative history that the courts should be permitted to impose their own limitations on the exercise of this jurisdiction, and no basis exists in traditional equity doctrine to authorize the limitations. Moreover, it is difficult to believe that the consequences of federal, rather than state, adjudication of these matters would be any more disastrous than the exercise of the federal diversity jurisdiction in many other areas of state concern. ${ }^{137}$ Judge Posner has suggested several plausible practical justifications for the probate exception, including promotion of legal certainty and judicial economy. ${ }^{138}$ While these arguments could arguably justify a legislatively imposed exception to the diversity jurisdiction, these practical considerations are certainly not so overwhelming as to fall within the concept of a "safety valve" rationale. Finally, Congress itself has imposed limitations on diversity jurisdiction, in the terms of the jurisdictional grant itself ${ }^{\mathbf{1 3 2}}$ as

133. See Note, Application of the Federal Abstention Doctrines to the Domestic Relations Exception to Federal Diversity Jurisdiction, 1983 DukE L.J. 1095.

134. C. Wright, supra note 1, at 143-44. In Dragan v. Miller, 679 F.2d 712 (7th Cir. 1982), cerl. denied, 459 U.S. 1017 (1983), Judge Posner noted that the probate exception had only "shoddy" historical underpinnings; "there was no ecclesiastical court in America, and it is not obvious why the language of the Judiciary Act of 1789 should be taken to refer exclusively to English rather than American courts." 679 F.2d at 713. He also cited the uncertain scope of the ecclesiastical court's exclusive jurisdiction. Id. Nevertheless, Judge Posner concluded that the probate exception is too well established a feature of our federal system to be lightly discarded, and by an inferior court at that, even if we were to reject as artificial the proposition that Congress's failure to repeal the exception when reenacting from time to time the grant of diversity jurisdiction to the Id. federal courts indicates congressional acquiescence.

135. Note, supra note 133 , at 1097.

136. C. WRIGHT, supra note 1, at 144; Note, supra note 133, at 1099.

137. For example, Professor Meador has argued that all personal injury cases arising under state law should be statutorily excluded from diversity jurisdiction. Meador, A New Approach to Limiting Diversity Jurisdiction, 46 A.B.A. J. 383 (1960).

138. Dragan v. Miller, 679 F.2d 712, 714 (7th Cir. 1982), cert. denied, 459 U.S. 1017 (1983).

139. For example, the diversity statute, 28 U.S.C. $\$ 1332$ (a) (1982), extends diversity jurisdiction 
well as in separate statutes. ${ }^{140}$ Congress has thus not generally ceded to the courts the province of developing limitations on the exercise of the diversity jurisdiction.

The only conceivable distinction between these forms of partial abstention and the others is that these are inherently limited to the exercise of the diversity jurisdiction, ${ }^{141}$ which has for many years been the subject of considerable debate and criticism, ${ }^{142}$ as well as of numerous moves in Congress for repeal or severe limitation. ${ }^{143}$ Moreover, the Supreme Court has, in construing the terms of the diversity grant, developed principles of questionable logic that function only to serve the thinly-veiled goal of curbing the scope of the diversity grant. ${ }^{144}$ One might therefore argue that the basis for an implied delegation to the judiciary is somewhat stronger in the diversity area than in other exercises of federal jurisdiction. Ultimately, however, there exists no real basis upon which to distinguish abstention in the diversity context. Although diversity jurisdiction is frequently disparaged, Congress has consistently refused to abolish or even limit the scope of the diversity grant. Moreover, there is no rational basis upon which to distinguish the probate and domestic relations areas from numerous other areas of state concern; general dislike of diversity jurisdiction cannot serve to justify select treatment of these two subjects. If one were to succeed in building an implied delegation rationale to justify diversity abstention, then separation-of-powers principles would require concrete and direct evidence that Congress actually intended such a delegation. Those who have argued in support of diversity abstention to date have not attempted to provide such evidence.

only to "civil actions where the matter in controversy exceeds the sum or value of $\$ 10,000$, exclusive of interest and costs. ..."

140. For example, 28 U.S.C. $\$ 1359$ (1982) provides that "[a] district court shall not have jurisdiction of a civil action in which any party, by assignment or otherwise, has been improperly or collusively made or joined to invoke the jurisdiction of such court." See Kramer v. Caribbean Mills, Inc., 394 U.S. 823 (1969) (applying § 1359).

141. Other forms of partial abstention either apply only to constitutional challenges to state action or else apply to multiple bases of federal jurisdiction.

142. E.g., H. Friendly, Federal Jurisdiction: A General. View 139-52 (1973).

143. See, e.g., H.R. 761, 95th Cong., 1st Sess., 123 Cong. Rec. 361 (1977); H.R. 9622, 95th Cong., 1st Sess., 123 Cong. Rec. 34124 (1977); H.R. 10050, 95th Cong., 1st Sess., 123 Cong. Rec. 37089 (1977); H.R. 5546, 95th Cong., 1st Sess., 123 Cong. Rec. 8744 (1977); H.R. 9123, 95th Cong., 1st Sess., 123 Cong. Rec. 29523 (1977); H.R. 7243, 95th Cong., 1st Sess., 123 Cong. Rec. 15153 (1977); H.R. 9308, 95th Cong., 1st Sess., 123 Cong. Rec. 30989 (1977).

144. See, e.g., Zahn v. International Paper Co., 414 U.S. 291 (1973) (narrow construction of the words "matter in controversy" in the diversity statute, for purposes of measuring jurisdictional amount); United Steel Workers of America v. R.H. Bouligny, Inc., 382 U.S. 145 (1965) (determination that, for purposes of diversity, a private association's citizenship is citizenship of each of its members, increasing likelihood of absence of complete diversity). 
Abstention

\section{The Total Abstention Model: Justifications and CRitique}

To my knowledge, no scholar or judge has ever expressly called upon the federal courts to ignore the congressional grant of jurisdiction to adjudicate suits against persons acting under color of state law for violations of 1 federal rights. ${ }^{145}$ However, several legal doctrines developed by the Justices, if accepted by a majority of the Court, could effectively exclude the lower federal courts from the exercise of their jurisdictional authority to enforce section 1983. In the discussion that follows, I describe the several theories and legal devices which make up the total abstention model.

\section{A. The State Judicial "Exhaustion" Theory}

Ironically, one finds the seeds of the most sweeping aspect of the total abstention model in the opinion that revitalized the section 1983 action after many years of dormancy. In Monroe v. Pape, ${ }^{146}$ the Court recognized a cause of action under section 1983 in a suit seeking damages from local police officers who allegedly violated plaintiffs' Fourth and Fourteenth Amendment rights against unreasonable search and seizure. ${ }^{147}$ The decision created an enormous stir, and was widely perceived as marking a new age in federal judicial activism against unconstitutional state conduct. ${ }^{148}$ The Court, per Justice Douglas, emphasized that a plaintiff need not exhaust his or her state judicial remedies, ${ }^{149}$ a conclusion which suggested expansive federal judicial authority to enforce section 1983. Discussing the history and purpose of the 1871 Givil Rights legislation, however, Justice Douglas noted that "it provided a remedy where state law was inadequate,"150 and that its aim "was to provide a federal remedy where the state remedy, though adequate in theory, was not available in practice."161 Justice Rehnquist-the leading architect of the total abstention model-has pointed to these statements in Monroe in urging a "reconsideration" of Monroe's no-judicial-exhaustion rule. The statutory purposes cited in Monroe, Justice Rehnquist argues, "need not bar exhaustion where the State can demonstrate that there is an available and adequate state remedy." 152

145. The congressional grant is codified at 28 U.S.C. $\S 1343(a)(3)$ (1982); 42 U.S.C. § 1983 (1982).

146. 365 U.S. 167 (1961).

147. Id. at 170.

148. See Shapo, Constitutional Tort: Monroe v. Pape and the Frontiers Bejond, 60 Nw. U.L. REv. 277 (1965).

149. 365 U.S. at 183 .

150. Id. at 173 .

151. Id. at 174 .

152. City of Columbus v. Leonard, 443 U.S. 905, 911 (1979) (Rehnquist, J., dissenting from 
An obvious difficulty with Justice Douglas' conclusion is that neither the substantive nor the jurisdictional statutes provide a federal remedy only "when state law was inadequate." The absence of such language probably reflects a congressional decision to allow the plaintiff to make that determination for him or herself. Indeed, at another point in Monroe, Justice Douglas seems to contradict his earlier purpose analysis by noting that "[a]lthough the legislation was enacted because of the conditions that existed in the South at that time, it is cast in general language and is as applicable to Illinois as it is to the States whose names were mentioned over and again in the debates."153

It may, at first, appear inaccurate to characterize Justice Rehnquist's statement as urging a form of "total" abstention. First, he suggests merely exhaustion of state judicial remedies, which one might reasonably believe would only delay federal adjudication, not preclude it. Second, he purports to leave open the possibility of federal court adjudication where the state is unable to demonstrate the existence of an adequate remedy. As a practical matter, however, acceptance of Justice Rehnquist's suggestion would amount to total federal abstention.

The term "exhaustion" in this context is a euphemism. In situations not involving section 1983, a requirement of exhaustion of state remedies, whether administrative ${ }^{\mathbf{1 5 4}}$ or judicial, ${ }^{\mathbf{1 5 5}}$ would result simply in a delay of federal court adjudication. When, and only when, the required state remedies had been sought, the plaintiff could return to federal court for adjudication of a federal claim. Such a practice has its disadvantages, but at least at some point a federal court may exercise its jurisdiction to adjudicate the federal claim. A requirement of state judicial exhaustion, on the other hand, would have no such result. We could, I suppose, structure our system so that a plaintiff who completed the state judicial adjudication of state remedies could return to federal court. This is, in fact, exactly what happens under habeas corpus ${ }^{156}-$ a device which Professor Cover has described as "diachronic or sequential redundancy."157 But outside the expressly contemplated exception in the habeas corpus model, this jurisdictional route is unavailable to plaintiffs, as Justice Rehnquist was no doubt aware when he urged reconsideration of the use of "exhaustion" of state judicial remedies in section 1983 actions.

denial of certiorari).

153. 365 U.S. at 183.

154. The administrative exhaustion requirement for $\S 1983$ suits was firmly rejected by the Supreme Court in Patsy v. Board of Regents, 457 U.S. 496 (1982).

155. See 28 U.S.C. $\S 2254(\mathrm{~b})(1982)$.

156. 28 U.S.C. $\S 2254$ (1982).

157. Cover, The Uses of Jurisdictional Redundancy: Interest, Ideology, and Innovation, 22 WM. \& MARY L. Rev. 639, 646 (1981). 
The Supreme Court held in Allen v. McCurry ${ }^{158}$ that the doctrine of collateral estoppel-the binding effect of a finding of fact or of a mixed question of law and fact in a previous state judicial action on a subsequent federal action-barred section 1983 plaintiffs. Under the Full Faith and Credit Act, ${ }^{169}$ a federal court must employ the broader doctrine of res judicata, which bars litigation of any aspect of the same cause of action or any claim arising out of the same operative facts which might have been brought. ${ }^{160}$ Since it is well established that state and federal courts have concurrent jurisdiction over section 1983 suits, ${ }^{161}$ a failure to raise a section 1983 claim in the course of the state judicial action would bar a subsequent federal suit.

Perhaps Justice Rehnquist intended to imply that if the Court were to impose a state judicial exhaustion requirement, the doctrines of collateral estoppel and res judicata would be abandoned. However, he gave no such indication, and it is highly unlikely that he would intend this result. Not surprisingly, those who call for one or another form of state judicial exhaustion generally endorse the Allen decision. ${ }^{162}$ Much the same philosophy lies behind both: a belief in the extensive use of state courts as the forum for the adjudication of federal constitutional challenges to state action. ${ }^{163}$ Hence, one must assume that Justice Rehnquist did not intend to abandon the dictates either of Allen or of the Full Faith and Credit Act when he called for reconsideration of the exhaustion of state judicial remedies in section 1983 actions. Thus structured, the so-called exhaustion requirement does considerably more than delay lower federal court adjudication; it effectively precludes it, leaving section 1343-the jurisdictional component of section 1983-a null set.

It is probably safe to assume that Justice Rehnquist did not intend a probing case-by-case inquiry. ${ }^{184}$ In theory, it is true that his analysis still

\footnotetext{
158. 449 U.S. 90 (1980).

159. 28 U.S.C. § 1738 (1982).

160. See, e.g., F. James \& G. Hazard, Crvil, Procedure $\S 11.2$ at 531 (2d ed. 1977); ReSTATEMENT (SECOND) OF JUDGMENTS $\$ 18$ (1982).

161. See Allen v. McCurry, 449 U.S. 90, 96 (1980).

162. See, e.g., Bator, supra note 63 , at 616 .

163. Professor Bator has written:

The participation of the state courts in the formulation and application of federal constitutional principles is, after all, the explicit premise of the supremacy clause, and has been deeply engrained in our institutional structures since the beginning. Its legitimacy and desirability are buttressed by an enormous tradition of federalistic rhetoric, running in an unbroken line from the Federalist Papers down to today's Supreme Court opinions.

Bator, supra note 63 , at 606 (footnotes omitted).

164. One clear indication that Justice Rehnquist's "adequacy" analysis of available state remedies would be something less than fully rigorous appeared in his opinion for the Court in Parratt v. Taylor, 451 U.S. 527 (1981). There, by means of substantive constitutional analysis, Justice Rehnquist effectively adopted his state exhaustion requirement, at least in certain cases. See discussion supra pp. 98-101. He found the state tort remedy adequate in that case, even though it failed to afford all of the substantive advantages of a section 1983 suit. 451 U.S. at 543-44.
} 
leaves room for federal judicial action where state remedies are found inadequate. But a detailed, probing, case-by-case federal judicial inquiry into the adequacy of substantive and procedural state remedies necessarily entails a significant increase in the federal courts' workload and in the frictions of judicial federalism. Indeed, it is the fear of these very dangers that has caused the Supreme Court to render all but useless the Civil Rights Removal Statute, ${ }^{165}$ even though the statutory language expressly calls for such a case-by-case inquiry. ${ }^{168}$

How an "adequacy" analysis would work in practice is candidly illustrated by Professor Bator, who has endorsed a similar approach (albeit in a somewhat more limited context):

[T] he "full and fair opportunity" formula leaves untouched the more subtle and invisible aspects of comparative competence. Indeed, it does not purport to be a technique for measuring the state judge's competence and sensitivity at all. If we are fundamentally suspicious of the state court system-if the central problem continues to be the problem of mistrust-then the "full and fair opportunity" formula will not do. I realize, too, that much will turn on the spirit in which the "full and fair opportunity" formula is interpreted in the various specific contexts to which it is relevant. Nevertheless, it is a virtue of this formula that it asks a question about the hospitable nature of the state courts rather than starting with an adverse presumption about it. ${ }^{167}$

Most states will provide theoretically adequate tort remedies for any conduct that amounts to a substantive violation of section $1983 .{ }^{168}$ Since neither Justice Rehnquist nor Professor Bator accepts the traditional institutional arguments for state court inadequacy, ${ }^{\mathbf{1 6 9}}$ only in those rare

165. 28 U.S.C. $\S 1443$ (1982) provides in relevant part:

Any of the following civil actions or criminal prosecutions, commenced in a State court may be removed by the defendant to the district court of the United States for the district and division embracing the place wherein it is pending:

(1) Against any person who is denied or cannot enforce in the courts of such State a right under any law providing for the equal civil rights of citizens of the United States, or of all persons within the jurisdiction thereor ....

The statute finds its origins in $\S 3$ of the Civil Rights Act of 1866, ch. $31, \S 3,14$ Stat. 27.

166. See City of Greenwood v. Peacock, 384 U.S. 808 (1966); Virginia v. Rives, 100 U.S. 313 (1879); see also Redish, Revitalixing Civil Rights Removal Jurisdiction, 64 MinN. L. REv. 523, 524-26 (1980) (courts should permit removal where a state defendant is unable to enforce his federal right to equality in state court).

167. Bator, supra note 63, at 626-27 (footnotes omitted). Professor Bator purported to consider, "at least directly," only those cases "where state enforcement courts must and will adjudicate federal constitutional defenses unless some affirmative intervention occurs to 'reroute' the federal question into a federal district court." Id. at 611 n.16.

168. Id. at 626-27.

169. For Justice Rehnquist's views, see Moore v. Sims, 442 U.S. 415, 430-31 (1979) (state proceedings offer adequate opportunity to raise constitutional claims). For Professor Bator's views, see 
cases in which the entire state judicial process is glaringly inadequate, would either of them be willing to find that state procedural remedies did not provide a plaintiff with a "full and fair opportunity" to litigate. Thus, while purists might quibble with my characterization of Justice Rehnquist's call for a state judicial exhaustion requirement as a form of total abstention in section 1983 suits, in reality that is exactly what Justice Rehnquist seeks.

\section{B. Expansion of Pullman Abstention into Total Abstention}

Pullman abstention itself cannot be deemed an element in the total abstention model, since it will be used only in the relatively rare situations in which the challenged state law is ambiguous. A minor modification of the doctrine, however, could shift it toward the total abstention model.

There are two ways to transform Pullman abstention into total abstention. One alternative, suggested by Chief Justice Burger's dissent in Wisconsin $v$. Constantineau, ${ }^{\mathbf{1 7 0}}$ is to expand the doctrine into a state judicial exhaustion requirement. Traditionally, Pullman abstention applies only when the challenged state law presents the ambiguity. On rare occasions, however, the Court has employed the doctrine when the state constitution contains a provision that might invalidate the state law without a federal constitutional challenge. ${ }^{171}$ In Constantineau, the Court appeared to have limited this branch of the doctrine to situations in which the state constitution provides a unique and specialized form of protection. ${ }^{172}$ The Chief Justice, however, was unwilling to limit resort to state constitutional remedies to such special cases. ${ }^{173}$ Since virtually every state constitution contains a protection similar or identical to the Fourteenth Amendment's due process and equal protection clauses, it would be a rare case indeed in which the Chief Justice would not order federal abstention ${ }^{174}$ in a case challenging the constitutionality of a state statute.

The second alternative, articulated by Justice Rehnquist, represents an equally clear modification of the doctrine into a type of total abstention. In a decision in which Pullman abstention was not at issue, ${ }^{175}$ Justice Rehnquist's opinion for the Court suggested that "[a]lmost every constitu-

generally Bator, supra note 63 .

170. 400 U.S. at $433,439-43$ (1971) (Burger, C.J., dissenting).

171. See Reetz v. Bozanich, 397 U.S. 82 (1970).

172. 400 U.S. 433.

173. Though the Chief Justice acknowledged that the state law was probably unconstitutional, he contended that it was "a very odd business to strike down a state statute, on the books for almost 40 years, without any opportunity for the state courts to dispose of the problem either under the Wisconsin Constitution or the U.S. Constitution." 400 U.S. at 440.

174. In the context of this discussion, one must recall the applicability of the principles of res judicata and collateral estoppel. See discussion supra p. 107.

175. Moore v. Sims, 442 U.S. 415 (1979). 
tional challenge . . o offers the opportunity for narrowing constructions that might obviate the constitutional problem and intelligently mediate federal constitutional concerns and state interests."178 Justice Rehnquist did not take this totally unsupported assertion to its logical conclusion ${ }^{177}$ - that a federal court should abstain in every federal constitutional challenge to a state statute. However, when combined with a logical interpretation of Justice Rehnquist's suggested "reconsideration" of a state judicial exhaustion requirement, this analysis provides the final piece to the total abstention model, creating a structure that effectively precludes the exercise of federal court jurisdiction under section 1343 to adjudicate federal constitutional challenges to any form of state action, and that instead places primary, if not exclusive, responsibility for the protection of federal rights in the state judiciaries.

\section{The Separation-of-Powers Critique of the Total Abstention Model}

The separation-of-powers attack on the total abstention model is, at least prima facie, a relatively simple and seemingly irrebuttable one. In a constitutional democracy, the unrepresentative judiciary may overrule the policy judgments of an electorally accountable legislative body only when those judgments violate the Constitution. The courts may not ignore or overrule congressional policy decisions because of simple disagreement with their wisdom.

While the concept of partial abstention might conceivably be justified through some notion of implied congressional delegation, ${ }^{178}$ total abstention has no such defense available. For it is all but inconceivable that Congress would impliedly delegate to the courts the authority in effect to repeal an entire substantive or jurisdictional legislative scheme. Nevertheless, three arguments could conceivably be advanced in support of the total abstention model. None of these, however, can adequately support the existence of the sweeping incursion on the legislative prerogative contemplated by the total abstention model.

\section{The Social Policy Argument in Favor of State Adjudication}

A proponent of total abstention might defend the model by contending that adoption of the principle in no way represents a repeal of section 1983 , since the concept simply makes the state judiciaries the primary

176. Id, at $429-30$.

177. Moore ultimately relied on Younger, because the federal court action sought to interfere with an ongoing state proceeding. Therefore, the Court did not have to consider the broader abstention issue.

178. See supra pp. 78-81. 


\section{Abstention}

enforcers of the substantive federal rights-a power which they are constitutionally competent to exercise. This argument fails for two reasons. First, it disregards the primary motivating force behind the legislation. The legislative intent-which has been well documented by commentators $^{\mathbf{1 7 9}}$ and the Court itself ${ }^{\mathbf{1 8 0}}$ - was to interpose the federal judiciary between the individual and the state, largely because of the failure of the state courts adequately to protect the individual. Second, the total abstention model conflicts not so much with the substantive directive of section 1983 as with the jurisdictional directive of section 1343. While section 1983 could conceivably coexist with a scheme supplementing federal judicial enforcement by state adjudication, it is logically inconceivable that section 1343 could survive such a move. If, as a practical matter, the federal courts completely forego their jurisdiction to enforce section 1983, the jurisdictional statute is inescapably rendered a nullity.

The response that the status of the state courts in the 1870's is irrelevant to their status in the 1980 's must be directed to the legislative body rather than the judiciary. As Justice Douglas noted in Monroe, ${ }^{181}$ the legislation as it currently stands is absolute in its terms: It does not limit the federal cause of action only to the southern states, or only to situations where the state remedy is found to be inadequate. Indeed, when the postCivil War Congress intended federal jurisdiction to turn upon the adequacy of the state court remedy, it explicitly stated its intention, as it did in the Civil Rights Removal Statute. ${ }^{182}$ The contrast between such contingent, case-by-case application of federal jurisdiction to protect federal rights and the unqualified, all-encompassing directive for enforcement of section 1983 underscores the clear congressional intent to avoid having the exercise of federal jurisdiction turn on the viability of the state remedy in

179. See Zeigler, supra note 5. Cf. H. Hyman, A More Perfect Union: The Impact of the Givil War and Reconstruction on the Constitution 528-42 (1973) (comprehensive discussion of Reconstruction legislation); S. KUTLER, Judicial POWER AND ReCONSTruction Polrtics 143-59 (1968) (discussion of removal statutes and congressional expansion of federal court jurisdiction); Wiecek, The Reconstruction of Federal Judicial Power, 1863-1875, 13 AM. J. LEGAL. Hist. 333 (1969) (discussing expansion of federal jurisdiction during Reconstruction).

180. According to the Court's decision in Mitchum v. Foster:

The predecessor of $\S 1983$ was . . . an important part of the basic alteration in our federal system wrought in the Reconstruction era through federal legislation and constitutional amendment. As a result of the new structure of law that emerged in the post-Civil War era-and especially of the Fourteenth Amendment, which was its centerpiece-the role of the Federal Government as a guarantor of basic federal rights against state power was clearly established.

407 U.S. 225, 238-39 (1972) (footnote omitted). The Court observed that "Tplroponents of the legislation noted that state courts were being used to harass and injure individuals, either because the state courts were powerless to stop deprivations or were in league with those who were bent upon abrogation of federally protected rights." Id. at 240 . See also Patsy v. Board of Regents, 457 U.S. 496, 503 (1982) (citing Mitchum).

181. 365 U.S. at 183 (discussing § 1979). See discussion supra pp. 105-06.

182. See discussion supra p. 108. 
the individual case. In the Givil Rights Removal Statute, Congress made access to federal courts contingent upon an objective judicial finding of the state judiciary's inadequacy in the particular case. In the precursor to section 1343, Congress made access contingent on a purely subjective choice, to be made by the individual seeking to vindicate his federal right against state intrusion. Therefore, the commonly employed argument that abstention is justified because of the fungibility of state and federal courts is unacceptable.

\section{The Jurisdictional Discretion Rationale}

Even accepting the questionable supposition that the substantive directive of section 1983 is not undermined by exclusive state judicial enforcement, the total abstention model cannot be defended from the separationof-powers attack on the ground that the judiciary would be departing only from a jurisdictional directive, rather than a substantive congressional program. Indeed, Justice Rehnquist himself-the primary architect of the incremental total abstention model-has often expressed an overriding concern with congressional intent in the fashioning of jurisdictional allocations, at least when the result has been to decrease the reach of federal court power. ${ }^{183}$

The Supreme Court has recognized the important interrelations between congressional jurisdictional allocations and substantive congressional programs when the state courts have refused to obey a jurisdictional directive, even when such refusals theoretically would not have rendered the substantive legislation a nullity. ${ }^{184}$ While the normative institutional principle may be different (separation of powers, rather than federalism), one could apply the same logic to a federal court's refusal to adhere to the congressional allocation of jurisdiction. Thus, an argument that construes a jurisdictional statute as somehow vesting a power in the federal courts to adjudicate the relevant claims without a corresponding duty to do so is unacceptable. Though federal jurisdictional statutes have traditionally been framed in terms that might conceivably lead to such a construction, ${ }^{185}$ the absurd results that would flow from that construction make it

183. For example, in Aldinger v. Howard, 427 U.S. 1 (1976), Justice Rehnquist, speaking for the Court, held that a federal court could not assert pendent party jurisdiction over a state claim against a municipality in a $\S 1983$ suit, in part because Congress had not intended that municipalities be subject to liability under $\S 1983$. Id. at 16-17.

184. Cf. Testa v. Katt, 330 U.S. 386 (1947) (state cannot refuse to enforce federal policies); M. REDisH, supra note 1, at 129-38 (state court refusal to adjudicate federal causes of action frustrates federal policy that case load created by a federal statute be shared by the two judicial systems).

185. Jurisdictional statutes generally provide that " $t$ ] $]$ he district courts shall have original jurisdiction of . . . " Though one might suggest that this language is not inherently mandatory, the use of the term "shall" tends to undermine such an argument. 


\section{Abstention}

clear that Congress could not have intended such an interpretation. Under such a structure, every substantive right created by Congress would effectively be subject to a practical veto by the federal judiciary: If a jurisdictional grant is merely an invitation to exercise jurisdiction, there is no logical reason why a federal court could not choose to disregard a particular federal statute-or a particular suit arising under a federal statute-which the Court deemed inadvisable. Surely, then, a congressional provision of jurisdiction must mean more than simply the option for the federal court to act. While perhaps Congress could constitutionally delegate such discretionary authority to the federal judiciary, absent a much clearer legislative directive we must assume that Congress did not intend such a dubious result.

\section{The Analogy to the Political Question Doctrine}

If one were to seek a precedent for the total abstention model, the logical starting point would be the political question doctrine. This doctrine "holds that certain matters are really political in nature and best resolved by the body politic rather than suitable for judicial review . . . "188 The political question doctrine cannot, however, directly authorize total abstention since the doctrine has been limited to situations in which another branch of the federal government is involved. ${ }^{187}$ Nevertheless, one could argue that the political question doctrine establishes a category of cases which the federal courts have declined to adjudicate, even though those cases clearly fall within a congressional grant of jurisdiction.

Not all agree, however, that the political question doctrine authorizes such discretionary judicial power to abstain from the exercise of jurisdiction. Professor Wechsler, for example, has argued that "the only proper judgment that may lead to an abstention from decision is that the Constitution has committed the determination of the issue to another agency of government than the courts." ${ }^{.188}$ In other words, to be legitimate, a federal court's refusal to adjudicate a dispute between the political branches must be based on a substantive constitutional analysis of the Constitution's allocation of authority between the political branches, not on a discretionary refusal to adjudicate. Professor Henkin has gone so far as to question whether any special "political question" doctrine exists at all: "One needs no special doctrine to describe the ordinary respect of the courts for the political domain. If a political question is one which the Constitution com-

186. J. Nowak, R. Rotunda \& J. Young, ConstTtutional Law 109 (1983).

187. See Baker v. Carr, 369 U.S. 186, 210 (1962).

188. Wechsler, Toward Neutral Principles of Constitutional Law, 73 HARv. L. REv. 1, 9 (1959). 
mits to the political branches, our political life is full of them."189 While not all agree with this approach, ${ }^{\mathbf{1 8 0}}$ one can nevertheless respond to an attempted justification of the total abstention model by means of the political question analogy by questioning the legitimacy of that doctrine, to the extent it represents something more than substantive constitutional interpretation of the allocation of authority among the branches. If the judiciary declines to resolve sensitive disputes, the nation is effectively left in a constitutional state of nature, and the constitutional position that prevails will be the one that is politically or physically most powerful.

In any event, obvious differences separate the political question doctrine from the total abstention model. Unlike the total abstention model, the political question doctrine does not have the effect of repealing a specific jurisdictional grant. For the political question doctrine to result in an analogous usurpation of legislative authority, Congress would have to have enacted a statute that did nothing more than vest jurisdiction in the federal courts to adjudicate political questions. In such a case, the legitimate criticism of the political question doctrine would probably increase. Moreover, the political question doctrine does not undermine a carefully structured legislative scheme in which the federal courts play an important role. In the context of legislative-judicial disputes, the political question doctrine could conceivably be justified as a means of avoiding usurpation of congressional authority. While the total abstention model represents a judicial refusal to enforce substantive congressional legislation against state action, the political question doctrine constitutes a judicial refusal to challenge the exercise of congressional authority. Thus, though one might raise a separation-of-powers objection to the political question doctrine, it would be because of the judiciary's refusal to consider the constitutionality of an exercise of legislative authority. This is hardly the usurpation of legislative authority represented by the total abstention model.

\section{ConCLusion}

Judge-made abstention constitutes judicial lawmaking of the most sweeping nature. Although a federal court's decision to infer a private cause of action may arguably invade the legislative process, judge-made abstention presents a considerably greater risk of judicial usurpation. While judicial creation of private rights of action can undermine a care-

189. Henkin, Is There a "Political Question" Doctrine?, 85 YALE L.J. 597, 598-99 (1976).

190. See Bickel, The Supreme Court 1960 Tern-Foreword: The Passive Virtues, 75 Harv. L. REv. 40, 46 (1961). 


\begin{abstract}
Abstention
fully structured statutory goal only indirectly, judicial lawmaking through abstention can very directly undermine that goal.

Recognition that abstention amounts to judicial lawmaking shifts the focus of the abstention debate away from the comparative merits of the policies for and against the various forms of abstention and toward the issue of the institutional legitimacy of such action on the part of the judiciary. Well accepted principles of separation of powers mandate that an electorally accountable legislature make the basic policy decisions concerning how the nation is to be governed. The authority to make these policy decisions necessarily includes the authority to employ the federal judiciary to enforce the substantive statutory programs adopted by Congress. Absent a finding of unconstitutionality, it is not the judiciary's function to modify or repeal a congressional enforcement network unless Congress has clearly delegated such authority to the judiciary. No court or commentator has presented persuasive evidence of any congressional intent to delegate such authority. Indeed, throughout the nation's history, Congress has retained for itself the authority to decide when federal courts should decline to exercise their jurisdiction.

It may well be that, if Congress were to consider the matter today, it would choose to structure abstention much as the federal courts have. But the comparative arguments for and against such forms of abstention are by no means so one-sided as to make that conclusion inescapable. In a constitutional democracy, in any event, such decisions are most appropriately rendered by the legislature, not the judiciary.
\end{abstract}




\section{The Yale Law Journal}

Volume 94, Number 1, November 1984

\author{
Mark E. Haddad \\ Editor-in-Chief \\ Beth S. Brinkmann \\ Julia E. Guttman \\ Peter D. Keisler \\ Sarah Korn \\ Robert A. Long \\ Note Editors
}

\author{
Amy L. Henrich \\ Managing Editor
}

\author{
Lynn A. Baker \\ Anita Bernstein \\ Ronald D. Lee \\ Howard M. Shapiro \\ William M. Treanor \\ Article $\mathcal{E}$ Book Review Editors
}

\begin{abstract}
Pauline E. Calande Sharon A. Hooper Niki Kuckes

John R. Low-Beer
\end{abstract}

\section{Senior Editors}

David A. Martland Emily S. McMahon John B. Sandage Gene C. Schaerr Paul Schwartz

\section{Editors}

Robert S. Adelson Thomas P. Arden David M. Aronowitz Patrick A. Broderick Kenneth Ghristman Stephen M. Gutler David R. Dow

Deborah D. Dupire
Peter R. Ezersky

Sarah B. Gordon

Rosemary Herbert Alan Hirsch Kenneth C. Johnsen Howard Kruse Ronald J. Kuerbitz Christopher C. Magorian
Gene B. Sperling Peter P. Swire Stephen H. Willard Wendy A. Wolf

Business Manager: Pamela Standish Editorial Assistant: Rosemary B. Carey

\section{Student Contributors to this Issue}

Julia E. Guttman, Primary Elections and the Collective Right of Freedom of Association

Mark E. Haddad, Getting Results Under Section 5 of the Voting Rights Act

John R. Low-Beer, The Constitutional Imperative of Proportional Representation

Howard M. Shapiro, Geometry and Geography: Racial Gerrymandering and the Voting Rights Act 